\title{
Does the combined application of organic and mineral nutrient sources influence maize productivity? A meta-analysis
}

\author{
Pauline Chivenge $\cdot$ Bernard Vanlauwe $\cdot$ Johan Six
}

Received: 24 May 2010 /Accepted: 21 October 2010 /Published online: 12 November 2010

(C) The Author(s) 2010. This article is published with open access at Springerlink.com

\begin{abstract}
The combined application of organic resources (ORs) and mineral fertilizers is increasingly gaining recognition as a viable approach to address soil fertility decline in sub-Saharan Africa (SSA). We conducted a meta-analysis to provide a comprehensive and quantitative synthesis of conditions under which ORs, $\mathrm{N}$ fertilizers, and combined ORs with $\mathrm{N}$ fertilizers positively or negatively influence Zea mays (maize) yields, agronomic $\mathrm{N}$ use efficiency and soil organic $\mathrm{C}$ (SOC) in SSA. Four OR quality classes were assessed; classes I (high quality) and II (intermediate quality) had $>2.5 \%$ $\mathrm{N}$ while classes III (intermediate quality) and IV (low quality) had $<2.5 \% \mathrm{~N}$ and classes I and III had $<4 \%$ polyphenol and $<15 \%$ lignin. On the average, yield responses over the control were $60 \%, 84 \%$ and $114 \%$ following the addition of ORs, $\mathrm{N}$ fertilizers and ORs + $\mathrm{N}$ fertilizers, respectively. There was a general increase in yield responses with increasing OR quality and OR$\mathrm{N}$ quantity, both when ORs were added alone or with $\mathrm{N}$ fertilizers. Surprisingly, greater OR residual effects were observed with high quality ORs and declined
\end{abstract}

Responsible Editor: Hans Lambers.

P. Chivenge $(\bowtie) \cdot J$. Six

Department of Plant Sciences, University of California,

One Shields Ave,

Davis, CA 95616, USA

e-mail: pchivenge@gmail.com

B. Vanlauwe

TSBF-CIAT, ICRAF Campus,

United Nations Ave, P. O. Box 30677, Nairobi, Kenya with decreasing OR quality. The greater yield responses with ORs $+\mathrm{N}$ fertilizers than either resource alone were mostly due to extra $\mathrm{N}$ added and not improved $\mathrm{N}$ utilization efficiency because negative interactive effects were, most often, observed when combining ORs with $\mathrm{N}$ fertilizers. Additionally, their agronomic $\mathrm{N}$ use efficiency was not different from sole added ORs but lower than $\mathrm{N}$ fertilizers added alone. Nevertheless, positive interactive effects were observed in sandy soils with low quality ORs whereas agronomic use efficiency was greater when smaller quantities of $\mathrm{N}$ were added in all soils. Compared to sole added ORs, yield responses for the combined treatment increased with decreasing OR quality and greater yield increases were observed in sandy $(68 \%)$ than clayey soils (25\%). While ORs and ORs $+\mathrm{N}$ fertilizer additions increased SOC by at least $12 \%$ compared to the control, $\mathrm{N}$ fertilizer additions were not different from control suggesting that ORs are needed to increase SOC. Thus, the addition of ORs will likely improve nutrient storage while crop yields are increased and more so for high quality ORs. Furthermore, interactive effects are seldom occurring, but agronomic $\mathrm{N}$ use efficiency of ORs $+\mathrm{N}$ fertilizers were greater with low quantities of $\mathrm{N}$ added, offering potential for increasing crop productivity.

Keywords Organic resource quality Interactive effects $\cdot$ Integrated soil fertility management $\cdot$ Yield response $\cdot$ Meta-analysis $\cdot$ Agronomic $\mathrm{N}$ use efficiency $\cdot \mathrm{N}$ fertilizer 


$\begin{array}{ll}\text { Abbreviations } \\ \text { OR(s) } & \text { Organic resource(s) } \\ \text { SSA } & \text { Sub-Saharan Africa } \\ \text { SOC } & \text { Soil organic carbon } \\ \text { MAP } & \text { Mean annual precipitation }\end{array}$

\section{Introduction}

Enhanced food crop production in sub-Saharan Africa (SSA) is critically dependent on external nutrient inputs, especially $\mathrm{N}$ and $\mathrm{P}$. This is mainly because of negative soil nutrient balances caused by continuous cultivation with little or no addition of nutrients (Cobo et al. 2010; Sanchez 2002; Smaling et al. 1997). While mineral fertilizers are widely used globally to overcome nutrient deficiencies, their use remains very low in SSA with average application rates of $8 \mathrm{kgha}^{-1} \mathrm{yr}^{-1}$ (Crawford and Jayne 2010; Morris et al. 2007; Smaling 2006). Fertilizer use has been limited mainly because of low availability and lack of purchasing capacity by the smallholder farmers in SSA (Morris et al. 2007). Ironically, in SSA, where more than half the population lives on less than US $\$ 1$ day $^{-1}$, fertilizer costs are two to eight times more expensive than in the rest of the world (Bationo et al. 2006).

Organic resources (ORs), ranging from animal manures, household composts, crop residues, leguminous cover crops, to leguminous and non-leguminous trees and shrubs, are often used as major nutrient sources to crops. However, their use in most African cropping systems is usually limited by low availability (Giller et al. 1998; Mugwira and Murwira 1997; Rufino et al. 2010). Application of ORs usually leads to increased crop yields (Kimetu et al. 2004; Mugwira 1984; Vanlauwe et al. 2001b) but depressed yields with OR use have also been reported (Mugwira and Murwira 1997; Nhamo 2002). The differential yield responses following OR application have been attributed mainly to differences in OR quality and soil fertility status (Giller and Cadisch 1995; Koné et al. 2008; Palm et al. 2001a). Quality of ORs is often defined using their N, lignin and polyphenol concentrations (Constantinides and Fownes 1994; Melillo et al. 1982). Based on the same parameters, Palm et al. (2001a) proposed four OR quality classes and developed a decision support tool for the management of OR N.
They proposed to directly apply high quality ORs which have a fast nutrient release, class I $(>2.5 \% \mathrm{~N},<4 \%$ polyphenol, $<15 \%$ lignin) and to surface apply low quality ORs, class IV $(<2.5 \% \mathrm{~N},>15 \%$ lignin $)$ for erosion control. Class IV ORs induce $\mathrm{N}$ immobilization that can last for extended periods of time. On the other hand, intermediate quality ORs, i.e. class II $(>2.5 \% \mathrm{~N},>4 \%$ polyphenol or $>15 \%$ lignin) and class III ORs ( $<2.5 \% \mathrm{~N},<4 \%$ polyphenol, and $<15 \%$ lignin), are to be added in combination with $\mathrm{N}$ fertilizers to alleviate a slow nutrient release due to biochemical recalcitrance for class II ORs and low $\mathrm{N}$ content for class III ORs.

The combined application of ORs and fertilizers is increasingly gaining recognition as one of the appropriate ways of addressing soil fertility depletion, especially in low-external input systems in SSA and forms an integral part of integrated soil fertility management (Vanlauwe et al. 2010a, 2002a). Greater yield benefits can be achieved following the combined application of ORs and fertilizers compared to either resource applied alone (Mucheru-Muna et al. 2007; Nziguheba et al. 2002; Vanlauwe et al. 2002a). Nutrient cycling and the associated yield benefits derived from combining ORs and fertilizers are dependent on a number of factors including climate, bio-physico-chemical soil environment and OR quality and there are intricate interactions among these factors (Chivenge et al. 2009; Giller and Cadisch 1995; Palm et al. 2001a). For example, Tian et al. (2007) observed increases in rate of decomposition and nutrient release with increase in OR quality in wetter climates but in drier climates decomposition and nutrient release was faster with low quality ORs than high quality ORs. Low quality ORs have a mulching effect that influence soil microclimate and thus enhance their decomposition (Lavelle et al. 1993; Tian et al. 2007, 1993).

While the combined addition of intermediate quality ORs with $\mathrm{N}$ fertilizers or the sole addition of high quality ORs can enhance nutrient cycling and increase crop yields, their effects on soil organic $\mathrm{C}$ (SOC) build-up may be negative. The addition of fertilizers with intermediate quality ORs may increase OR decomposition (Sakala et al. 2000; Zingore et al. 2003) and thus may result in reduced SOC stabilization compared to OR added alone. The addition of intermediate and low quality ORs may result in greater SOC concentrations than high quality ORs (Bossuyt et al. 2001; Six et al. 2001). However, recent 
studies have shown no long-term effects of OR quality on SOC dynamics (Chivenge 2008; Gentile et al. 2010). Nevertheless, there may be interactions with other factors such as soil texture and rainfall (Chivenge 2008; Feller and Beare 1997).

Although narrative reviews provide useful summaries of the knowledge of a given discipline, metaanalysis offers a more precise and quantitative synthesis of treatment effects by statistically comparing results from multiple studies (Gurevitch and Hedges 1999; Rosenburg et al. 2000). This approach has been borrowed primarily from medical, physical and behavioral sciences (Gurevitch and Hedges 1999) and has been used recently for ecological studies (de Graaff et al. 2006; Gurevitch et al. 2000; Knorr et al. 2005; van Groenigen et al. 2006) and agricultural experiments (Miguez and Bollero 2005; Sileshi et al. 2008; Tirol-Padre and Ladha 2006). Meta-analyses methods provide a robust synthesis of results from independent studies in a manner that is both objective and statistically defensible (Ainsworth et al. 2007; Hungate et al. 2009). Metaanalytic procedures were used in the current study to analyze the effects of the addition of ORs, $\mathrm{N}$ fertilizers and ORs in combination with $\mathrm{N}$ fertilizers on Zea mays (maize) productivity and SOC and interactions among different factors. Although publication and research bias cannot be ruled out, we believe that the studies included in this metaanalysis were sufficient to capture the diversity of soils, climate and OR quality classes that are generally used by smallholder farmers in SSA.

The objectives of this study were to provide a comprehensive and quantitative synthesis of conditions under which ORs, $\mathrm{N}$ fertilizers, and ORs $+\mathrm{N}$ fertilizers positively or negatively influence maize yields and SOC build-up. The specific objectives were to determine;

i) maize yield and $\mathrm{SOC}$ responses to the application of ORs, $\mathrm{N}$ fertilizers, and ORs $+\mathrm{N}$ fertilizers,

ii) the influence of OR quality, both when applied alone or in combination with $\mathrm{N}$ fertilizers, on maize yield and SOC responses,

iii) effects of OR-N and fertilizer-N quantities on maize yield and SOC responses,

iv) the interactive effects of combining ORs with $\mathrm{N}$ fertilizers and how these could be influenced by OR quality and OR-N quantities, v) the interactions of the above with soil texture and mean annual precipitation (MAP).

\section{Materials and methods}

Database compilation

We identified 57 studies carried out in smallholder farms and experimental stations under rain-fed field conditions in SSA where ORs and $\mathrm{N}$ fertilizers were added separately and in combination with each other (See Appendix 1). To be included in our metaanalysis, the studies should have reported maize yields following the combined addition of ORs with $\mathrm{N}$ fertilizers, sole ORs, and/or sole $\mathrm{N}$ fertilizers. Data from the same experiment but reported in more than one publication were not repeated, the publication with the most complete dataset was used. Twelve of the 57 studies also reported measurements of SOC. Published data reported in tables were taken directly from the publications while results presented in graphs were digitized and measured to estimate the values. Sixteen studies were carried out over a single season while only nine studies were carried out over at least 5 years. Twenty-three studies tested the repeated application of ORs over at least two seasons while five tested the residual effects of the ORs. Residual effects were estimated based on observations made in the second season when ORs were only applied in the preceding season and crops planted in both the first and second season. Crop residues were removed from the field for other uses such as fodder or were grazed in situ, except in cases where they were used as the OR treatment.

The studies used in the meta-analysis covered 104 experimental field sites in 12 countries in SSA (Benin, Burkina Faso, Cote d'Ivoire, Ethiopia, Ghana, Kenya, Malawi, Nigeria, Tanzania, Togo, Zambia, and Zimbabwe) and represent the humid rainforest, the moist savanna, the dry savanna, the sudano sahelian, and the guinea savanna agroecological zones. Amounts of $\mathrm{N}$ supplied by ORs ranged from 6 to $547 \mathrm{kgNha}^{-1}$ annually; while fertilizer-N ranged from 20 to $175 \mathrm{kgNha}^{-1}$ per season; and the total $\mathrm{N}$ in the combined treatments ranged between 33 and $667 \mathrm{kgNha}^{-1}$ annually. The ranges of $\mathrm{N}$ addition differentiated in the current meta-analysis (Table 1) are based on the $\mathrm{N}$ response 
Table 1 Categorical variables used in describing the experimental conditions

\begin{tabular}{|c|c|c|c|c|}
\hline Categorical variable & Level 1 & Level 2 & Level 3 & Level 4 \\
\hline Soil texture & Sand $(<20 \%$ clay $)$ & Loam ( $20-32 \%$ clay) & Clay ( $>32 \%$ clay) & \\
\hline Mean annual precipitation & $\begin{array}{l}\text { Low } \\
<600 \mathrm{~mm}\end{array}$ & $\begin{array}{l}\text { Medium } \\
600-1000 \mathrm{~mm}\end{array}$ & $\begin{array}{l}\text { High } \\
>1000 \mathrm{~mm}\end{array}$ & \\
\hline Organic resource class ${ }^{\mathrm{a}}$ & $\begin{array}{l}\text { Class I }>2.5 \% \mathrm{~N}, \\
<4 \% \text { polyphenol, } \\
<15 \% \text { lignin }\end{array}$ & $\begin{array}{c}\text { Class II }>2.5 \% \mathrm{~N} \\
>4 \% \text { polyphenol } \\
\text { or }>15 \% \text { lignin }\end{array}$ & $\begin{array}{l}\text { Class III }<2.5 \% \mathrm{~N}, \\
<4 \% \text { polyphenol, } \\
<15 \% \text { lignin }\end{array}$ & $\begin{array}{c}\text { Class IV }<2.5 \% \mathrm{~N} \\
>4 \% \text { polyphenol } \\
\text { or }>15 \% \text { lignin }\end{array}$ \\
\hline Organic resource $\mathrm{N}$ & $\begin{array}{l}\text { Low } \\
\leq 30 \mathrm{kgNha}^{-1}\end{array}$ & $\begin{array}{l}\text { Medium } \\
30-100 \mathrm{kgNha}^{-1}\end{array}$ & $\begin{array}{l}\text { High } \\
>100 \mathrm{kgNha}^{-1}\end{array}$ & \\
\hline Fertilizer-N & $\begin{array}{l}\text { Low } \\
\leq 30 \mathrm{kgNha}^{-1}\end{array}$ & $\begin{array}{l}\text { Medium } \\
30-100 \mathrm{kgNha}^{-1}\end{array}$ & $\begin{array}{l}\text { High } \\
>100 \mathrm{kgNha}^{-1}\end{array}$ & \\
\hline
\end{tabular}

${ }^{\text {a }}$ Organic resource classification according to Palm et al. (2001a).

curve. The $0-30 \mathrm{kgNha}^{-1}$ and $31-100 \mathrm{kgNha}^{-1}$ ranges represent the linear and curve-linear parts of the $\mathrm{N}$ response curve, respectively whereas at $>100 \mathrm{~kg}$ $\mathrm{Nha}^{-1}$ the curve plateaus (Murwira et al. 2002; Oikeh et al. 1998; Vanlauwe et al. 2001a). However, it is worth noting that the $\mathrm{N}$ response varies from site to site and is dependent on other factors such as soil texture and climate (Bationo et al. 2005; Murwira et al. 2002). In order to calculate $\mathrm{N}$ addition rates of ORs, OR-N amounts were taken directly from the publications or were calculated based on the $\% \mathrm{~N}$ and quantities of ORs applied. Where the OR-N content was not reported but total added biomass was indicated, average \% $\mathrm{N}$ contents from the Organic Resource Database (Palm et al. 2001a) were used to estimate OR-N quantities added.

Mean annual precipitation ranged from 500 to $1800 \mathrm{~mm}$. The categories of MAP used in the meta analysis (Table 1) were based on precipitation and approximated FAO guidelines for agro-climatic zoning (Fischer et al. 2001). Soil textures ranged from sandy ( $2 \%$ clay; $98 \%$ sand) to clayey ( $75 \%$ clay; $10 \%$ sand) and the categorical textural classes are based on the textural triangle (Shirazi and Boersma 1984). Crop yield responses, interactive effects of combined application of ORs and $\mathrm{N}$ fertilizers, agronomic $\mathrm{N}$ use efficiency and SOC changes were used as the response variables. For the purposes of meta-analysis, we established discrete levels of the categorical variables and coded each variable (Table 1). Table 2 summarizes the number of observations for the categories.
Meta-analysis

Data was analyzed using MetaWin 2.1 software (Rosenburg et al. 2000). An effect size of each observation was calculated as the natural $\log$ of the response ratio (r). The response ratio was calculated using the equation:

$r=\mathrm{X}_{\mathrm{e}} / \mathrm{X}_{\mathrm{c}}$,

where $\mathrm{X}_{\mathrm{e}}$ is the mean for the treatment (i.e. ORs, $\mathrm{N}$ fertilizers, or ORs $\mathrm{N}+$ fertilizers) and $\mathrm{X}_{\mathrm{c}}$ is the mean of the control group (Rosenburg et al. 2000). Yields observed with the no input control were used as $\mathrm{X}_{\mathrm{c}}$ when control was compared to ORs, $\mathrm{N}$ fertilizers, or ORs $+\mathrm{N}$ fertilizers. Where the combined treatment was compared to either ORs or $\mathrm{N}$ fertilizers, $\mathrm{X}_{\mathrm{c}}$ was the mean of ORs or $\mathrm{N}$ fertilizer treatment, respectively, and $\mathrm{X}_{\mathrm{e}}$ was the mean for the combined treatment. For clarity, in figures presenting percent yield responses $\left[\left(\mathrm{X}_{\mathrm{e}}-\mathrm{X}_{\mathrm{c}}\right)^{*} 100 / \mathrm{X}_{\mathrm{c}}\right]$ under different treatments are compared to the control for ORs, $N$ fertilizers and ORs $+\mathrm{N}$ fertilizers, or to ORs or $\mathrm{N}$ fertilizers when the combined treatment was evaluated. Mean effect size for each categorical variable was calculated with bias-corrected $95 \%$ confidence intervals generated by the bootstrapping procedure in MetaWin using 4999 iterations. Maize yield responses and SOC changes to addition of ORs, $\mathrm{N}$ fertilizers, or $\mathrm{ORs}+\mathrm{N}$ fertilizers for each categorical variable were considered to be significant if the $95 \%$ confidence intervals did not overlap each other. 
Table 2 Summary of number of studies and data points of the observations made under different categories

\begin{tabular}{|c|c|c|c|c|c|c|c|c|c|c|c|c|}
\hline \multirow[t]{2}{*}{ Category } & \multirow[t]{2}{*}{ Level } & \multicolumn{4}{|c|}{ Organic resource quality class ${ }^{\mathrm{a}}$} & \multicolumn{4}{|c|}{ Organic resource $\mathrm{N}\left(\mathrm{kgNha}^{-1}\right)$} & \multicolumn{3}{|c|}{ Fertilizer $\mathrm{N}\left(\mathrm{kgNha}^{-1}\right)$} \\
\hline & & I & II & III & IV & $\begin{array}{l}\text { Low } \\
\leq 30\end{array}$ & $\begin{array}{l}\text { Medium } \\
31-100\end{array}$ & $\begin{array}{l}\text { High } \\
>100\end{array}$ & Residual & $\begin{array}{l}\text { Low } \\
\leq 30\end{array}$ & $\begin{array}{l}\text { Medium } \\
31-100\end{array}$ & $\begin{array}{l}\text { High } \\
>100\end{array}$ \\
\hline \multirow{4}{*}{ Soil texture } & \multicolumn{12}{|c|}{ Number of data points (number of studies) } \\
\hline & Sand & $75(5)$ & $75(5)$ & $232(18)$ & $30(2)$ & $98(11)$ & $127(10)$ & $99(5)$ & $59(2)$ & $22(6)$ & $143(13)$ & $168(4)$ \\
\hline & Loam & $87(11)$ & $73(10)$ & $188(13)$ & $30(2)$ & $45(6)$ & $77(10)$ & $152(10)$ & $52(4)$ & $6(1)$ & $151(14)$ & $184(4)$ \\
\hline & Clay & $135(11)$ & $167(12)$ & $348(19)$ & $24(2)$ & $71(18)$ & $85(15)$ & $112(7)$ & $50(1)$ & $16(4)$ & $546(23)$ & $169(7)$ \\
\hline \multirow{3}{*}{$\begin{array}{l}\text { Mean annual } \\
\text { precipitation } \\
(\mathrm{mm})\end{array}$} & $\leq 600$ & $58(2)$ & $46(1)$ & $113(6)$ & $10(1)$ & $52(7)$ & $48(6)$ & $22(2)$ & - & $48(7)$ & $46(4)$ & $50(1)$ \\
\hline & $\begin{array}{c}601- \\
1000\end{array}$ & 135 (13) & 95 (13) & $255(18)$ & $34(3)$ & 77 (9) & $162(13)$ & $135(8)$ & 67 (3) & - & $230(18)$ & $206(8)$ \\
\hline & $>1000$ & $152(11)$ & 209 (12) & $400(23)$ & $40(2)$ & 85 (10) & 387 (21) & $206(9)$ & 94 (3) & $16(4)$ & $564(26)$ & $265(6)$ \\
\hline
\end{tabular}

${ }^{\text {a } O r g a n i c ~ r e s o u r c e ~ c l a s s i f i c a t i o n ~ a c c o r d i n g ~ t o ~ P a l m ~ e t ~ a l . ~(2001 a) . ~}$

Interactive effects of the combined application of ORs with $\mathrm{N}$ fertilizers on maize yields were calculated according to Vanlauwe et al. (2001c) using the equation:

$$
\begin{aligned}
& \text { Interactive Effects }\left(\mathrm{kg} \mathrm{ha}^{-1}\right) \\
& \begin{array}{l}
=Y_{\text {comb }}-Y_{\text {con }}-\left(Y_{O R}-Y_{\text {con }}\right) \\
\quad-\left(Y_{\text {fert }}-Y_{\text {con }}\right)
\end{array}
\end{aligned}
$$

where $Y_{\text {con }}, Y_{\text {fert }}, Y_{O R}, Y_{\text {comb }}$ are mean grain yield $\left(\mathrm{kgha}^{-1}\right)$ in the control, the sole $\mathrm{N}$ fertilizers, the sole ORs and the ORs $+\mathrm{N}$ fertilizers, respectively. The interactive effects were considered to be significant if the $95 \%$ confidence interval did not overlap zero. Interactive effects represent extra maize grain yields obtained following the combined application of ORs with $\mathrm{N}$ fertilizers compared to the sum of the two when added separately (Vanlauwe et al. 2001c). Positive interactive effects imply extra grain yield whereas negative interactive effects show lower grain yield observed with the combined addition of ORs and $\mathrm{N}$ fertilizers compared to the addition of either resource alone. Since it was not possible to obtain the statistics for each of the interactive effects without the availability of all the raw data of all the replicates, we used an unweighted analysis where standard deviation was considered to be the same for all data. However, individual studies had different sample sizes but the calculated unweighted effect sizes would not take into consideration variances brought about by these different sample sizes.

Agronomic $\mathrm{N}$ use efficiency of the addition of ORs, $\mathrm{N}$ fertilizers or ORs $+\mathrm{N}$ fertilizers was calculated as the $\mathrm{kg}$ yield increase over the control per $\mathrm{kgN}$ applied (Cassman et al. 1998) using the equation:

$$
\begin{aligned}
& \text { Agronomic } N \text { use efficiency } \\
& \qquad=\frac{\left(Y_{\text {trt }}-Y_{\text {con }}\right)\left(k g h a^{-1}\right)}{\text { Total } N \text { applied }\left(k g N h a^{-1}\right)}
\end{aligned}
$$

Where $\mathrm{Y}_{\text {trt }}$ represents the yield for OR, $\mathrm{N}$ fertilizer, or $\mathrm{OR}+\mathrm{N}$ fertilizer treatments, $\mathrm{Y}_{\text {con }}$ represents the yield in the control treatment, and total $\mathrm{N}$ applied represents $\mathrm{N}$ applied in the $\mathrm{OR}, \mathrm{N}$ fertilizer or the combined treatment. Similar to interactive effects, an unweighted effect size was calculated for agronomic $\mathrm{N}$ use efficiency and used in the meta-analysis.

An unweighted effect size was also calculated and used for meta-analysis for SOC changes because some studies did not report standard deviations. In addition, since there were few studies that reported SOC measurements, it was essential not to omit studies and maintain a larger sample size. Effect sizes of ORs and ORs $+\mathrm{N}$ fertilizers over the no input control were calculated as the natural $\log$ of the response ratio of ORs or ORs $+\mathrm{N}$ fertilizers over the 
control. The initial $\mathrm{C}$ contents were not always available and hence SOC changes over time were not calculated.

Because there are many interactions among the factors that influence maize yield and SOC responses, agronomic $\mathrm{N}$ use efficiencies and interactive effects, there are many ways that the data could have been presented. However, we looked at the possible interactions and selected only the data that showed the most interesting trends.

\section{Results}

Maize yields

\section{Overall responses}

For all the treatments, i.e. ORs, $\mathrm{N}$ fertilizers and ORs + $\mathrm{N}$ fertilizers, maize yield responses over the control were greater when the control yield was low but as the yield of the control increased, the yield responses became smaller (Fig. 1). Additionally, most of the studies that had lower control yield but with greater yield responses were on sandy soils (Fig. 1).

Maize yield responses were positively influenced by the addition of ORs, $\mathrm{N}$ fertilizers and ORs $+\mathrm{N}$ fertilizers (Fig. 2a). The sole addition of ORs and $\mathrm{N}$ fertilizers resulted in $60 \%$ and $84 \%$ greater maize yields than the no input control, respectively (Fig. 2a). The combined application of ORs $+\mathrm{N}$ fertilizers more than doubled maize yields (114\%) compared to the no input control. The combined application of ORs $+\mathrm{N}$ fertilizers increased maize yields compared to sole applied ORs and $\mathrm{N}$ fertilizers by $33 \%$ and $17 \%$, respectively (Fig. 2b).

\section{Fertilizer- $N$ alone}

When sole $\mathrm{N}$ fertilizer was compared to the no input control, greater yield responses were observed in experiments where $\leq 30 \mathrm{~kg}$ fertilizer- $\mathrm{Nha}^{-1}$ was added compared to the control than when $31-100 \mathrm{~kg}$ fertilizer-Nha ${ }^{-1}$ was added (Fig. 3a). However, the yield difference between the control and the $\mathrm{N}$ fertilizer treatment was $936 \mathrm{kgha}^{-1}$ following the addition of $\leq 30 \mathrm{~kg}$ fertilizer-Nha ${ }^{-1}$ compared to $>1450 \mathrm{~kg}$ $\mathrm{ha}^{-1}$ when greater amounts of fertilizer-N were added
(Fig. 3b). Yield responses to $\mathrm{N}$ fertilizer addition were greater in clayey and sandy soils than loamy soils (Fig. 3a) but the yield difference was greatest in clayey soils, while there were no differences between loamy and sandy soils (Fig. 3b). Although maize yield responses were greater in areas receiving $\leq 600 \mathrm{~mm}$ MAP than in areas receiving 600-1000 mm MAP, absolute yield differences were lowest where MAP was $\leq 600 \mathrm{~mm}\left(691 \mathrm{kgha}^{-1}\right)$ whereas the yield difference was more than double in areas where MAP was $>600 \mathrm{~mm}\left(>1450 \mathrm{kgha}^{-1}\right.$; Fig. 3).

\section{Organic resource alone}

Organic resource quality and OR-N quantity added influenced maize yield responses, but interactions with soil texture were observed (Fig. 4). Independent of soil texture for sole applied ORs, greater yield responses were observed with ORs in classes I and II, but there were no differences between these two classes for all soil textures (Fig. 4a). Lowest yield responses were observed with class IV ORs, with depressed yields in sandy soils by up to $45 \%$ (Fig. 4a). Looking at all soils combined, there seems to be three distinct OR quality classes where classes I and II ORs would be combined into one class, i.e. high quality, whereas classes III and IV ORs would be the intermediate and low quality classes, respectively (Fig. 4a).

Overall, yield responses tended to increase with increasing OR-N quantity but distinct differences were only observed in clayey soils (Fig. 4b). Across all soil textures, mean yield responses were $100 \%$ in experiments where $>100 \mathrm{~kg}$ OR-Nha ${ }^{-1}$ was added, whereas in experiments where $<30 \mathrm{~kg}$ OR-Nha ${ }^{-1}$ was added, yield responses were only $8 \%$ (Fig. $4 \mathrm{~b}$ ). Residual effects of ORs applied in one season were positive in the subsequent season with crop yield responses of $38 \%$ over the no input control when all textures were combined but in sandy soils there were slightly negative but not significant (Fig. 4b). In clayey soils, residual effects of ORs were greater (49\%) than where $\leq 30 \mathrm{~kg}$ OR-Nha ${ }^{-1}(15 \%)$ was added but less than where greater OR-N quantities were added (Fig. 4b). Surprisingly, in the loamy soils, residual effects of ORs resulted in the greatest yield responses (69\%) which were, however, not significantly different from when $>100 \mathrm{~kg}$ OR-Nha ${ }^{-1}$ was added (Fig. 4b). 


\section{a OR vs control}

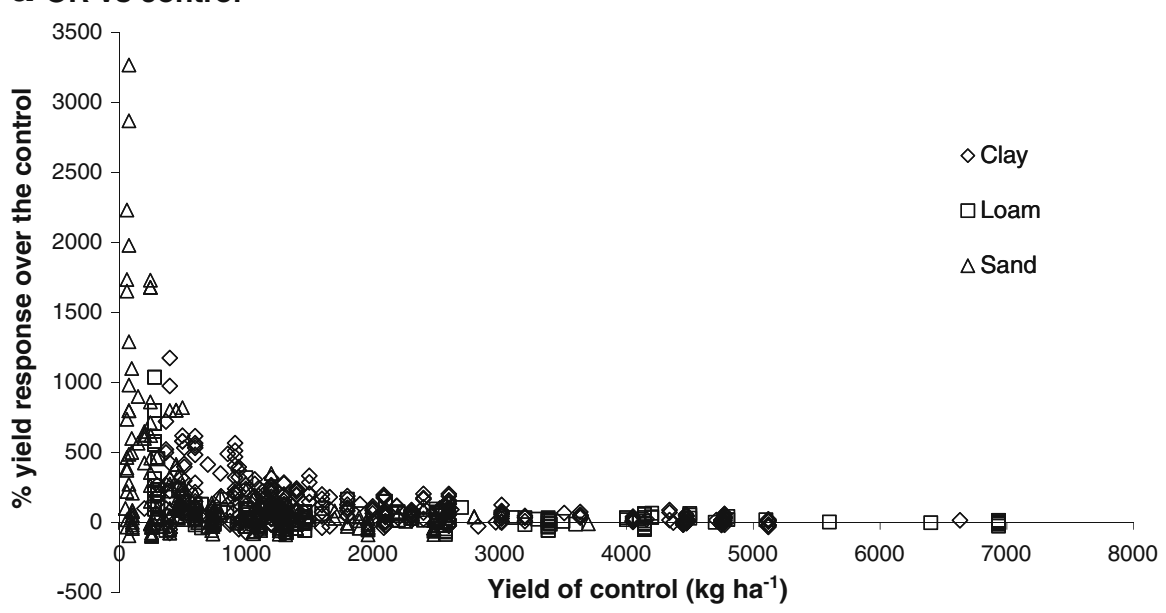

\section{b $\mathbf{N}$ fertilizer vs control}

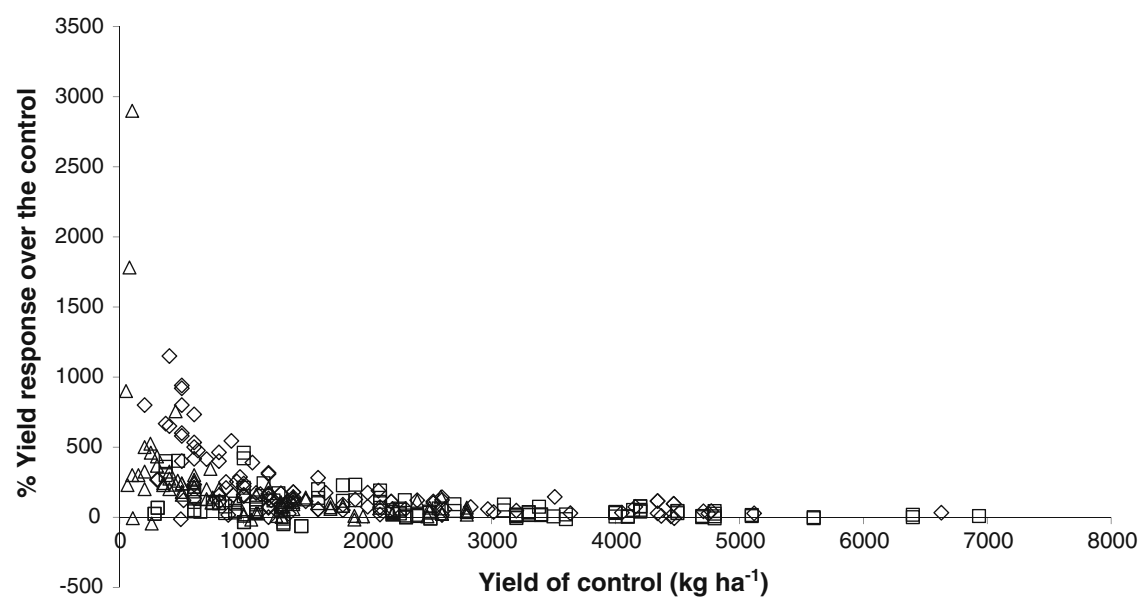

C OR + N fertilizer vs control

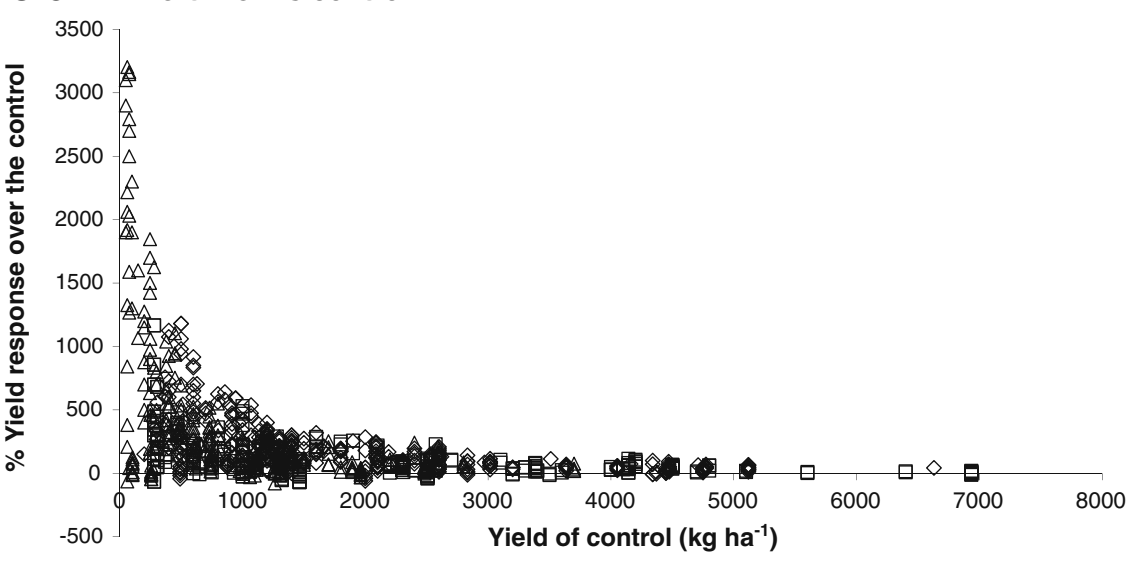

Fig. 1 The relationship of the yield responses over the no input control to the addition of a organic resources (ORs), b $\mathrm{N}$ fertilizers, and $\mathbf{c}$ ORs $+\mathrm{N}$ fertilizers with the yield of the control 


\section{a Overall responses vs control}

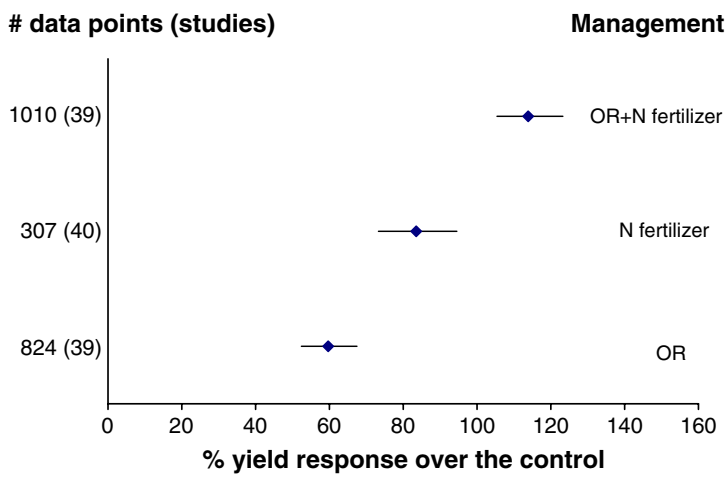

b Combined treatment vs OR or $\mathbf{N}$ fertilizer

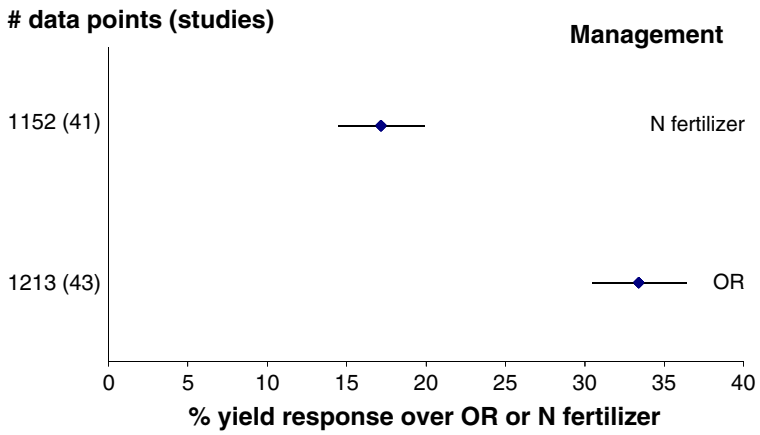

Fig. 2 Yield responses a to the addition of organic resources $(\mathrm{OR})$, mineral $\mathrm{N}$ fertilizers and the combined application of the two (OR $+\mathrm{N}$ fertilizer) compared to the no input control, and $\mathbf{b}$ of the combined treatment compared to sole mineral $\mathrm{N}$ fertilizers or sole ORs expressed as yield responses. Responses are expressed as weighted average response percentage with $95 \%$ confidence intervals represented by error bars. Numbers of effect size comparisons are given as \# of data points and number of studies from which the points are taken appear in parentheses

\section{Organic resources with $N$ fertilizers}

Yield responses increased with increasing OR quality when ORs were applied in combination with $\mathrm{N}$ fertilizers, but again there were interactions with soil texture. Across all textures, the greatest yield responses were observed with class II ORs but were not significantly different from class I ORs (Fig. 5a). Similar to sole added ORs, three distinct OR quality classes were recognizable when looking across all soils with classes I and II ORs clustering into one OR class of high quality residues, and class III and IV ORs forming the intermediate and low quality classes, respectively (Fig. 5a). Unlike sole added ORs, yield responses were positive for all OR quality classes in all soils (Fig. 5a). Yield responses also tended to increase with increasing quantities of OR-N added with a yield response of about $215 \%$ where $>100 \mathrm{~kg} \mathrm{OR}^{-\mathrm{Nha}^{-1}}$ in sandy and clayey soils (Fig. 5b). The addition of $\mathrm{N}$ fertilizers with residual ORs resulted in yield responses that were lower than where fresh ORs were added in the sandy and clayey soils. Again in the loamy soils residual OR effects resulted in greater yield responses but was not different from where $>100 \mathrm{~kg}^{\mathrm{OR}-\mathrm{Nha}^{-1}}$ was added (Fig. 5b).

\section{Residual effects of ORs}

The residual effects of ORs on yield responses, both when applied alone or in combination with $\mathrm{N}$ fertilizers, increased from class IV to class I ORs but there were no significant differences among OR classes I, II and III (Fig. 6). There were no residual effects for sole applied class IV ORs (Fig. 6a), but the addition of $\mathrm{N}$ fertilizers in the residual season increased crop yields, and the same was observed with other OR classes (Fig. 6b). In sandy soils and in areas receiving 601-1000 mm MAP, there were also no significant residual OR effects but were increased when $\mathrm{N}$ fertilizer was added (Fig. 6). However, the addition of $\mathrm{N}$ fertilizers resulted in no differences between sandy soils and the other textures and also between the MAP categories (Fig. 6b).

\section{Efficacy of ORs $+N$ fertilizers over sole ORs or $N$ fertilizers}

When the combined treatment was compared to sole ORs, yield responses tended to increase with decreasing OR quality, and were generally positive except in loamy soils where there were no differences between sole class IV OR and the combined treatment (Fig. 7a). Greater yield responses were observed in the sandy soils than finer textured soils; for class IV specifically; crop yield responses for ORs $+\mathrm{N}$ fertilizers over sole applied ORs were $249 \%$ compared to $\leq 35 \%$ in finer textured soils (Fig. 7a). In contrast, the combined application of class IV ORs with $\mathrm{N}$ fertilizers was not different from sole $\mathrm{N}$ fertilizer for all soils (Fig. 7b). Additionally, there was a general decline in maize yield responses with decrease in OR quality (Fig. 7b). Contrary to other soils, in the clayey soils yield responses of the combined treatment compared to sole $\mathrm{N}$ fertilizer were greatest $(25 \%)$ with class II ORs compared to $11 \%$ observed with classes I and III ORs, respectively (Fig. 7b). 
a $\mathbf{N}$ fertilizer vs control: \% Yield response

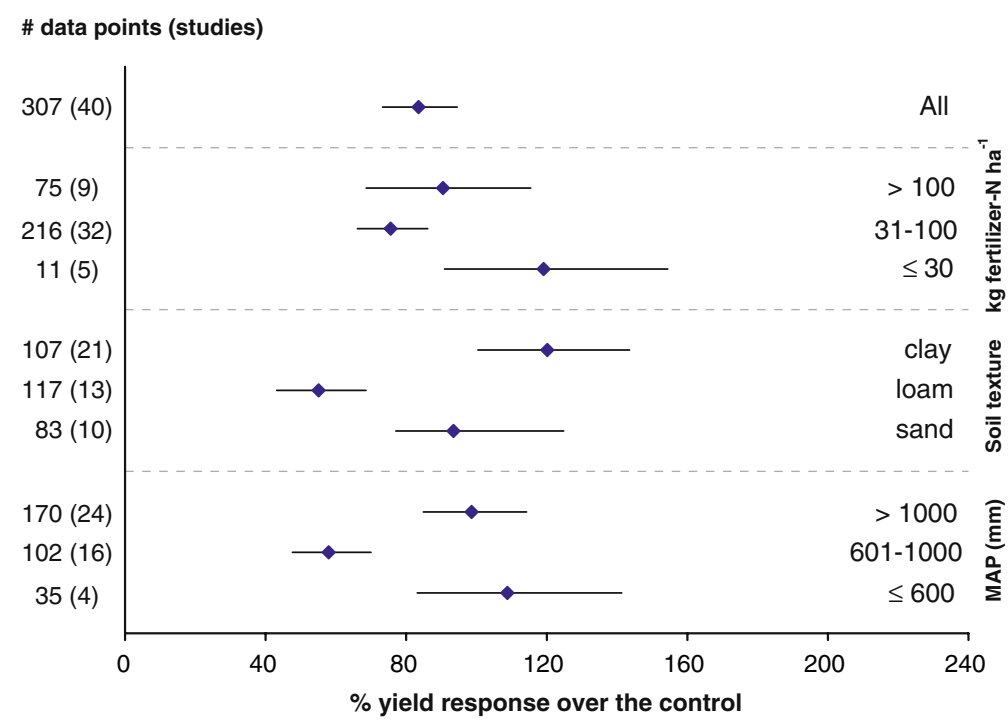

b N fertilizer vs control: Yield difference

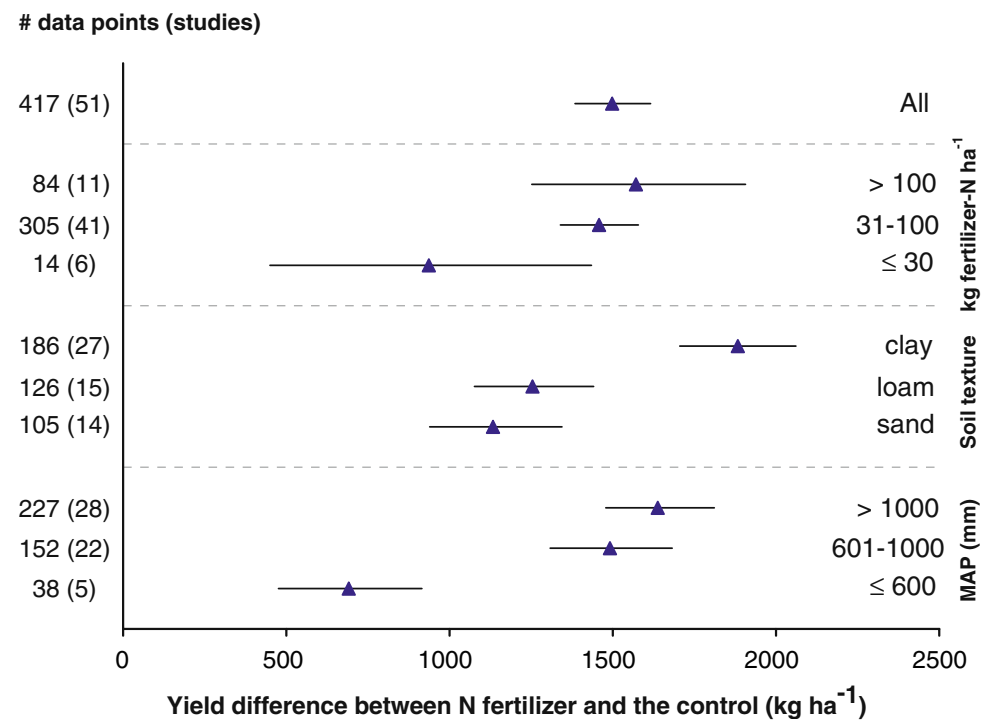

Fig. 3 Yield response to the addition of mineral $\mathrm{N}$ fertilizers compared to the no input control categorized into quantities of fertilizer-N applied $\left(\mathrm{kgNha}^{-1}\right)$, test crop, and mean annual precipitation (MAP) classes. Yield responses are expressed as average a response ratio percentage, and $\mathbf{b}$ absolute yield

Interactive effects of the combined application of ORs and $N$ fertilizer on maize yields

Overall, the addition of ORs $+\mathrm{N}$ fertilizers resulted in negative interactive effects on maize yields $(-445 \mathrm{~kg}$ ha $^{-1}$; Figs. 8 and 9), except in sandy and loamy soils difference, with $95 \%$ confidence intervals represented by error bars. Numbers of effect size comparisons are given as \# of data points and number of studies from which the points are taken appear in parentheses

of areas receiving $\leq 600 \mathrm{~mm}$ MAP (Fig. 8). While there was a general decrease in interactive effects with increasing MAP in sandy and clayey soils, there was no clear pattern for loamy soils (Fig. 8). Generally, interactive effects decreased with increasing OR quality with the most negative interactive effects 


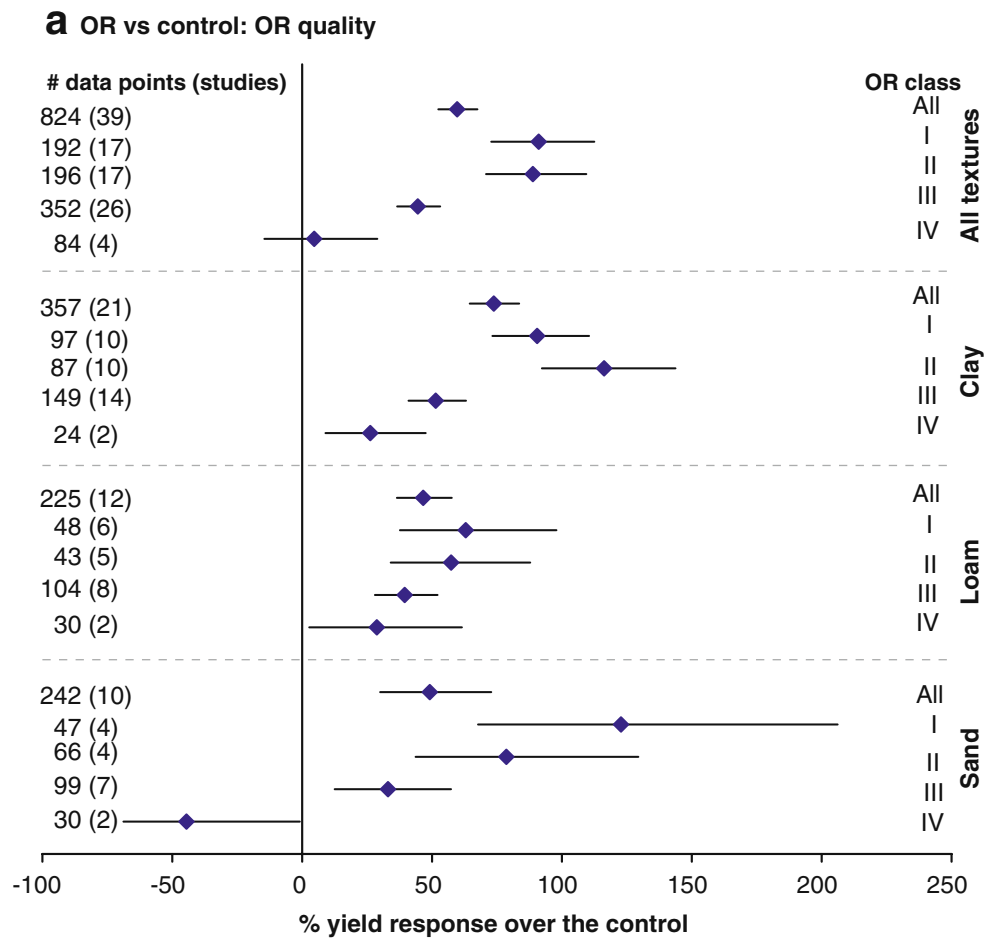

\section{b OR vs control: OR-N quantity}

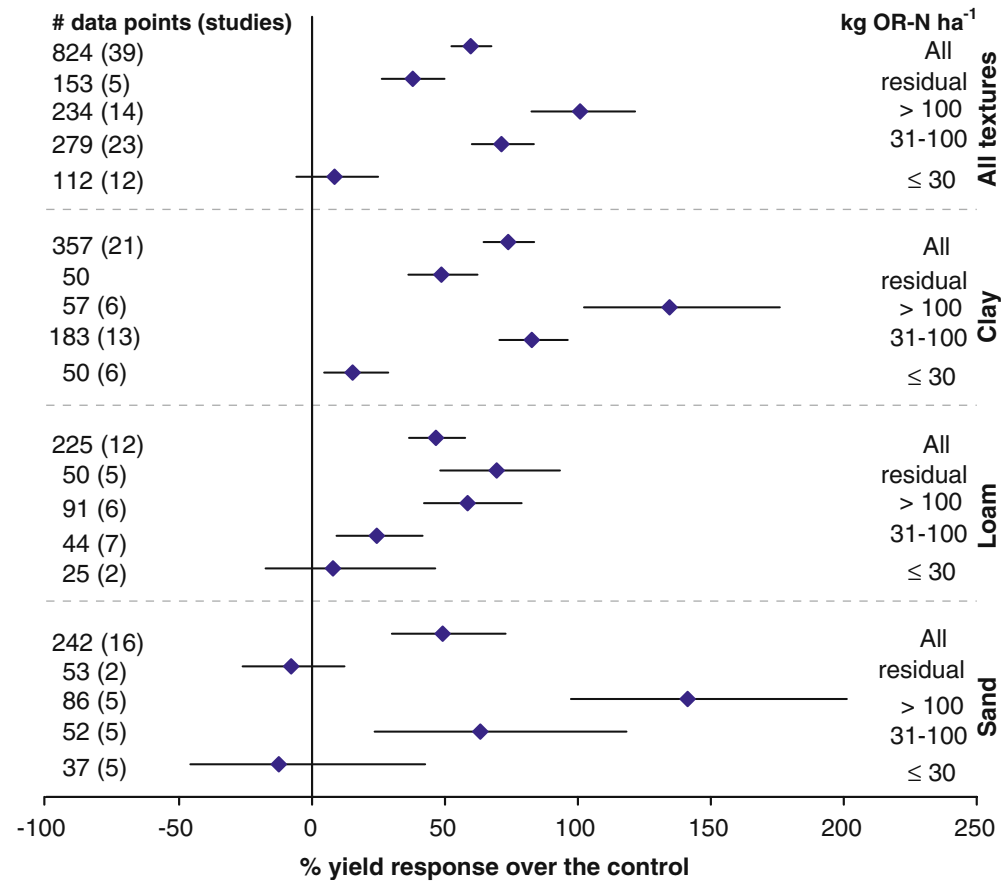

Fig. 4 Yield response to the addition of organic resources (OR) compared to the no input control categorized into a four quality classes (See Table 1), and b three OR-N quantities applied. Yields are expressed as weighted average response percentage with $95 \%$ confidence intervals represented by the error bars. Numbers of effect size comparisons are given as \# of data points and number of studies from which the points are taken appear in parentheses 
Fig. 5 Yield response to the combined addition of organic resources (OR) with mineral $\mathrm{N}$ fertilizers compared to the no input control categorized into a four OR quality classes (See Table 1), and b three OR-N quantities applied. Yield responses are expressed as weighted average response percentage with $95 \%$ confidence intervals represented by error bars. Numbers of effect size comparisons are given as \# of data points and number of studies from which the points are taken appear in parentheses

\section{a}

$\mathrm{OR}+\mathrm{N}$ fertilizer vs control: OR quality

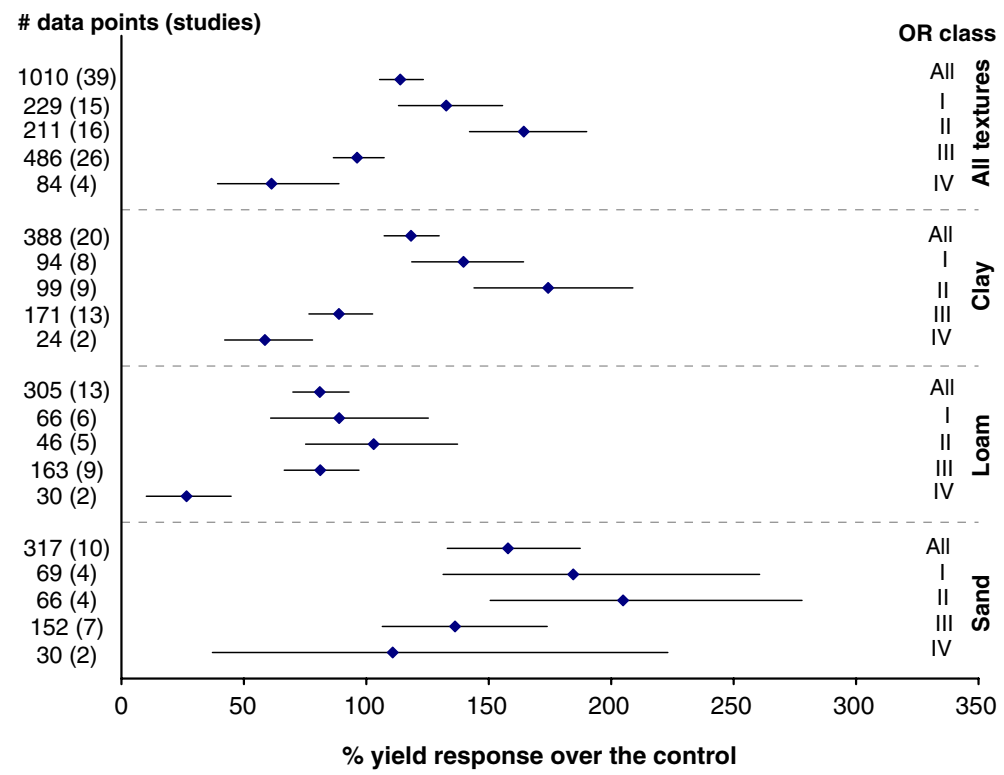

\section{b}

$\mathrm{OR}+\mathrm{N}$ fertilizer vs control: OR-N quantity

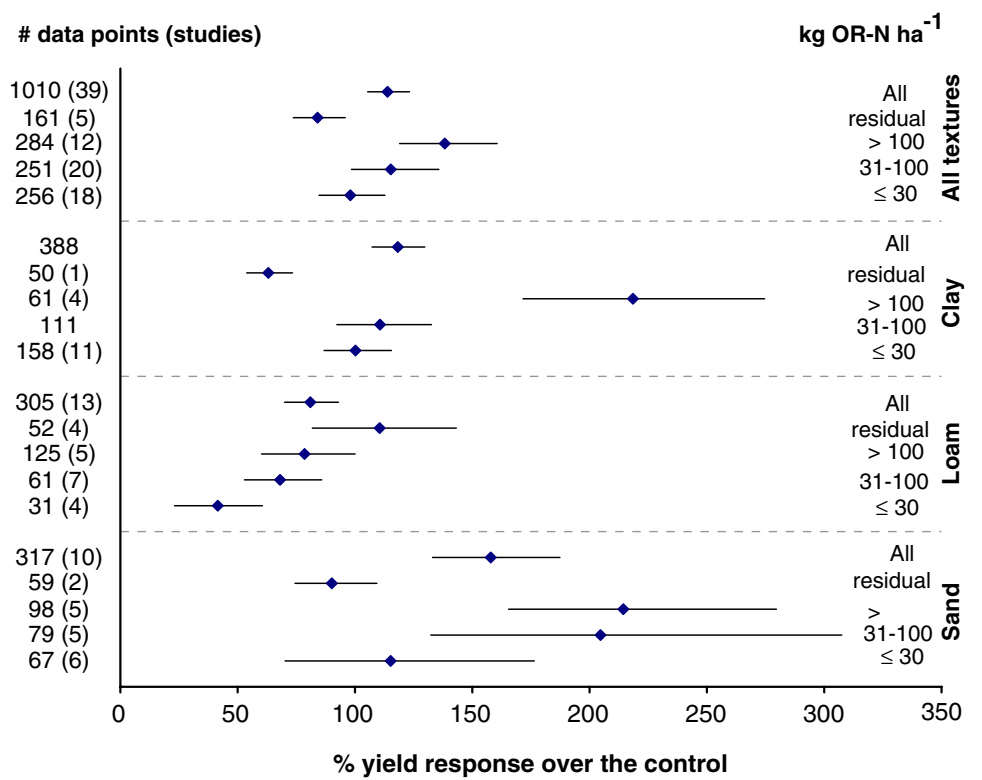

being observed with class I ORs in clayey and sandy soils (Fig. 9a). Although interactive effects were generally negative following the addition of ORs $+\mathrm{N}$ fertilizers in sandy soils, the combined application of class IV ORs with $\mathrm{N}$ fertilizers resulted in positive interactive effects, $360 \mathrm{kgha}^{-1}$ (Fig. 9a). Interestingly, when $\leq 30 \mathrm{~kg}$ OR-Nha ${ }^{-1}$ was added with $\mathrm{N}$ fertilizers in sandy soils, interactive effects tended to be positive (Fig. 9b). Surprisingly however, while interactive effects of residual OR-N effects with $\mathrm{N}$ fertilizers were negative or zero in clayey and sandy soils, respectively, in loamy soils they were $224 \mathrm{kgha}^{-1}$ (Fig. 9b). 
Fig. 6 Yield responses to residual effects of a organic resources (OR), and $\mathbf{b} \mathrm{OR}+$ mineral $\mathrm{N}$ fertilizers, compared to the no input control for three categorical variables, mean annual precipitation (MAP), soil texture, and OR quality classes (See Table 1). Responses are average percentages with 95\% confidence intervals represented by error bars. Numbers of effect size comparisons are given as \# of data points and number of studies from which the points are taken appear in parentheses a

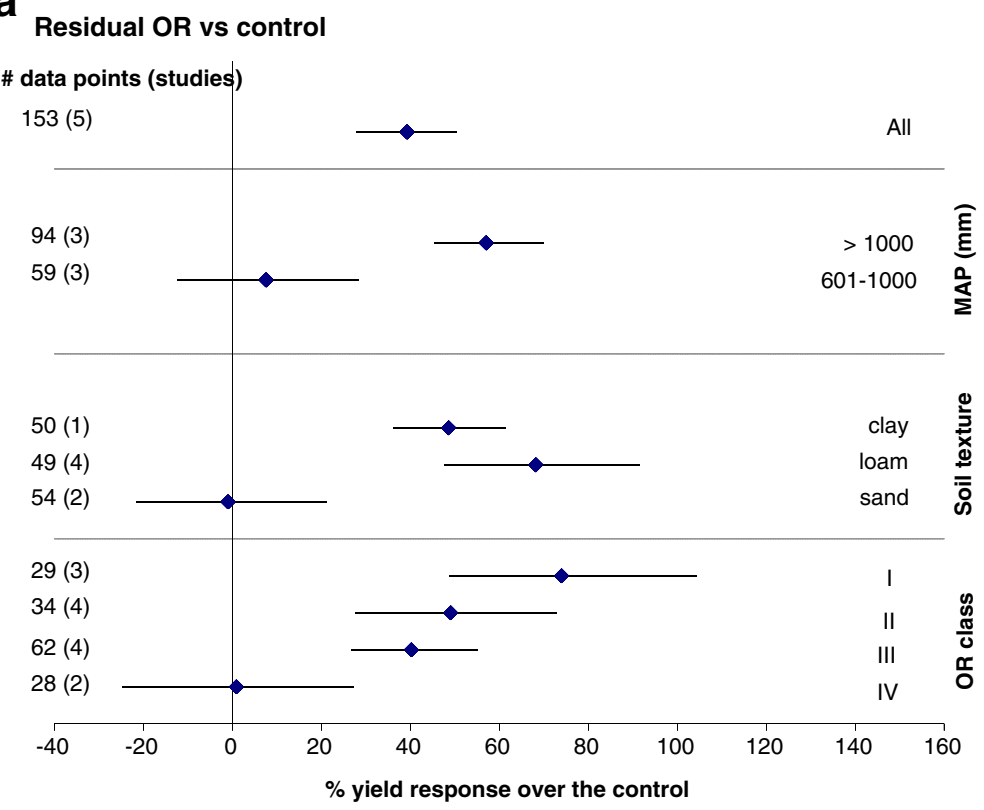

b

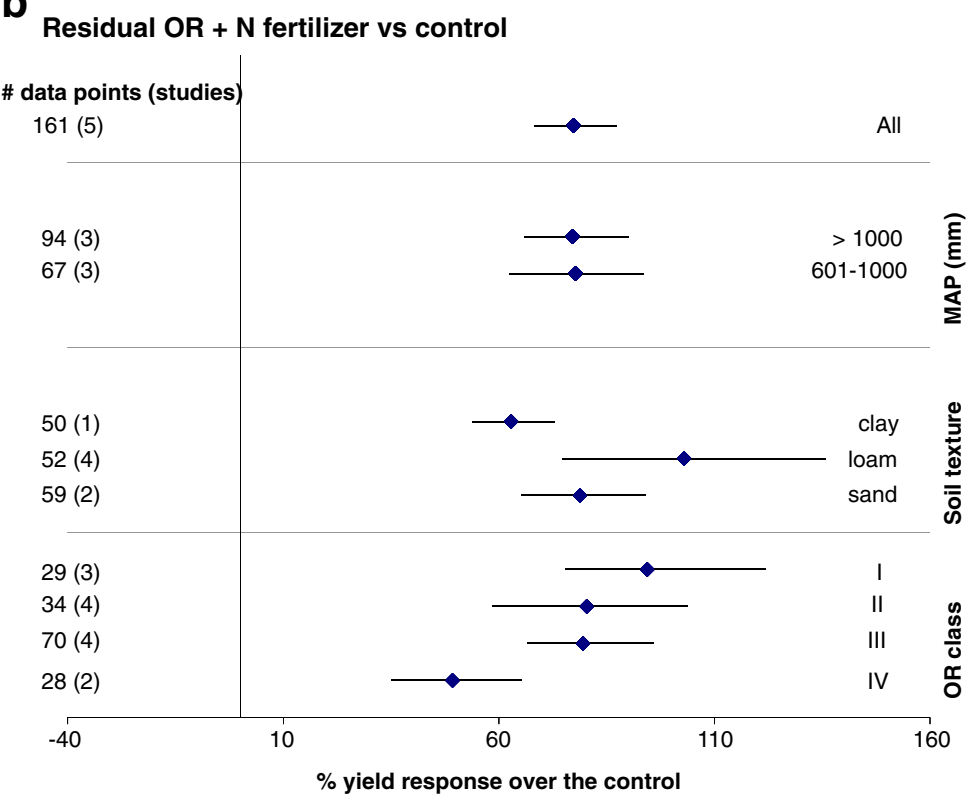

Agronomic $N$ use efficiency

Agronomic $\mathrm{N}$ use efficiency was greater following the addition of $\mathrm{N}$ fertilizers (22 kg grain increase $\mathrm{kg}^{-1} \mathrm{~N}$ applied) than ORs and ORs $+\mathrm{N}$ fertilizers which had agronomic $\mathrm{N}$ use efficiencies of 13.1 and $13.6 \mathrm{~kg}$ grain increase $\mathrm{kg}^{-1} \mathrm{~N}$ applied, respectively (Fig. 10a). When all soils were combined, agronomic $\mathrm{N}$ use efficiency of the combined treatment were lowest with class IV ORs but there were no differences among OR classes I, II and III (Fig. 10b). In sandy soils agronomic $\mathrm{N}$ use efficiency was $11.7 \mathrm{~kg}$ grain increase $\mathrm{kg}^{-1} \mathrm{~N}$ applied for class III ORs compared to $\leq 5 \mathrm{~kg}$ grain increase $\mathrm{kg}^{-1} \mathrm{~N}$ applied with classes II and IV ORs (Fig. 10b). In loamy soils, on the other hand, class III ORs resulted in agronomic $\mathrm{N}$ use efficiency, which was significantly greater than class I and IV ORs (Fig. 10b). Generally, there were no differences 
Fig. 7 Yield response to the combined addition of organic resources $(\mathrm{OR})$ with mineral $\mathrm{N}$ fertilizers compared to a sole OR and, $\mathbf{b}$ sole $\mathrm{N}$ fertilizer expressed as yield responses, categorized into the four OR quality classes (See Table 1) for clayey, loamy and sandy soils. Yield responses are expressed as weighted average response percentage with $95 \%$ confidence intervals represented by the error bars. Numbers of effect size comparisons are given as \# of data points and number of studies from which the points are taken appear in parentheses a

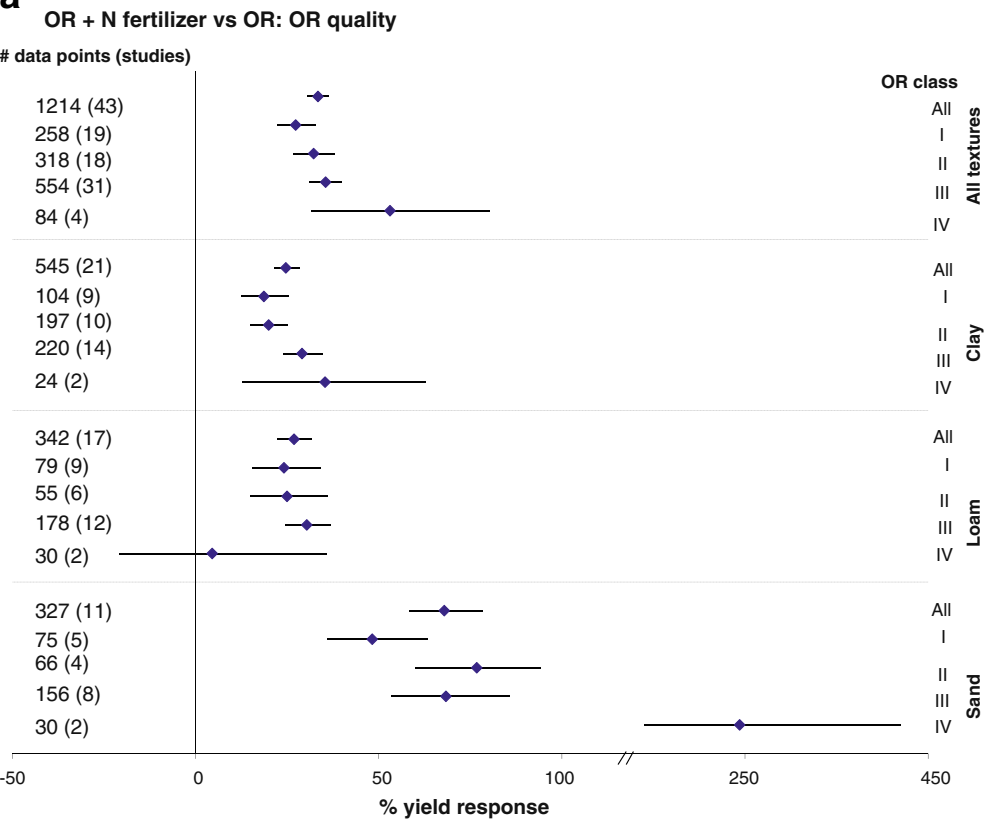

b

OR+N fertilizer vs $\mathrm{N}$ fertilizer: $\mathrm{OR}$ quality

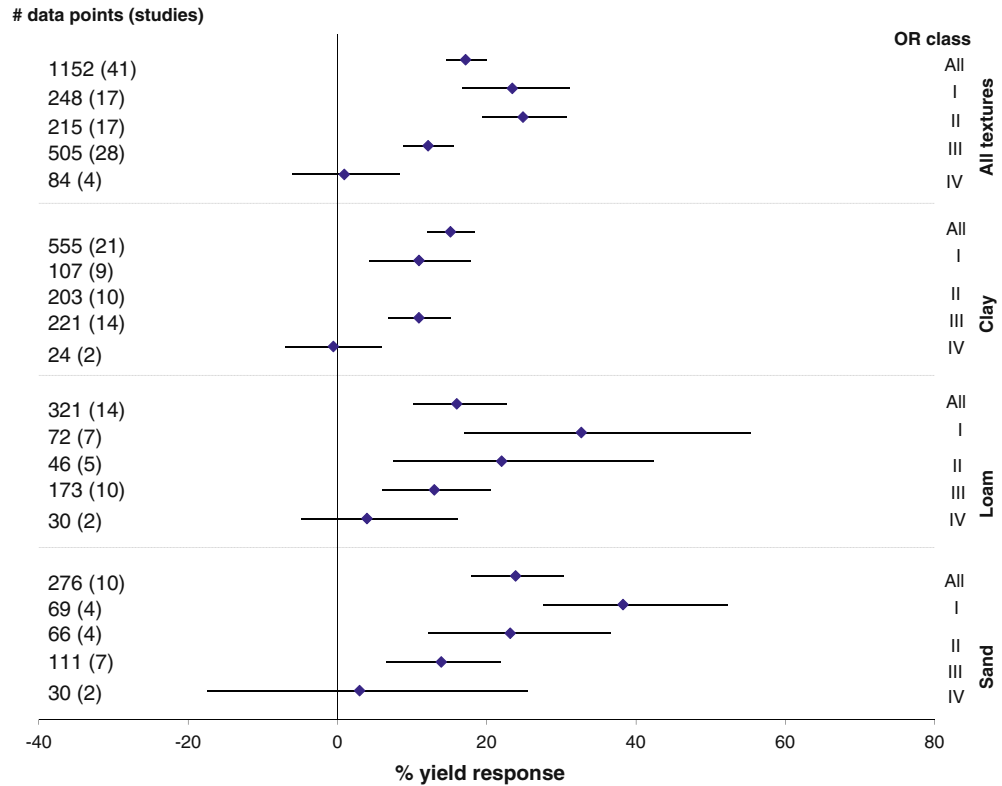

between OR classes I and II except in sandy soils where agronomic $\mathrm{N}$ use efficiency for class I ORs was twice as much that of class II ORs (Fig. 10b). Agronomic N use efficiency of the combined addition of ORs with $\mathrm{N}$ fertilizers increased with decreasing quantities of both OR-N and fertilizer-N, except in loamy soils where $\leq 30 \mathrm{~kg}$ OR-Nha ${ }^{-1}$ was not significantly different from when greater amounts of OR-N were added (Fig. 11a and b). The addition of $\leq 30 \mathrm{kgNha}^{-1}$ resulted in agronomic $\mathrm{N}$ use efficiencies of 20 and $31 \mathrm{~kg}$ grain increase $\mathrm{kg}^{-1} \mathrm{~N}$ added as ORs and $\mathrm{N}$ fertilizers, respectively across all textures (Fig. 11a and b). The combined addition of ORs and $\mathrm{N}$ fertilizers resulted in greater $\mathrm{N}$ use 
Fig. 8 Interactive effects of the combined addition of organic resources with $\mathrm{N}$ mineral fertilizers categorized into three mean annual precipitation (MAP) classes for clayey, loamy and sandy soils. Interactive effects $\left(\mathrm{kgha}^{-1}\right)$ are expressed as unweighted averages with 95\% confidence intervals represented by error bars. Numbers of effect size comparisons are given as \# of data points and number of studies from which the points are taken appear in parentheses

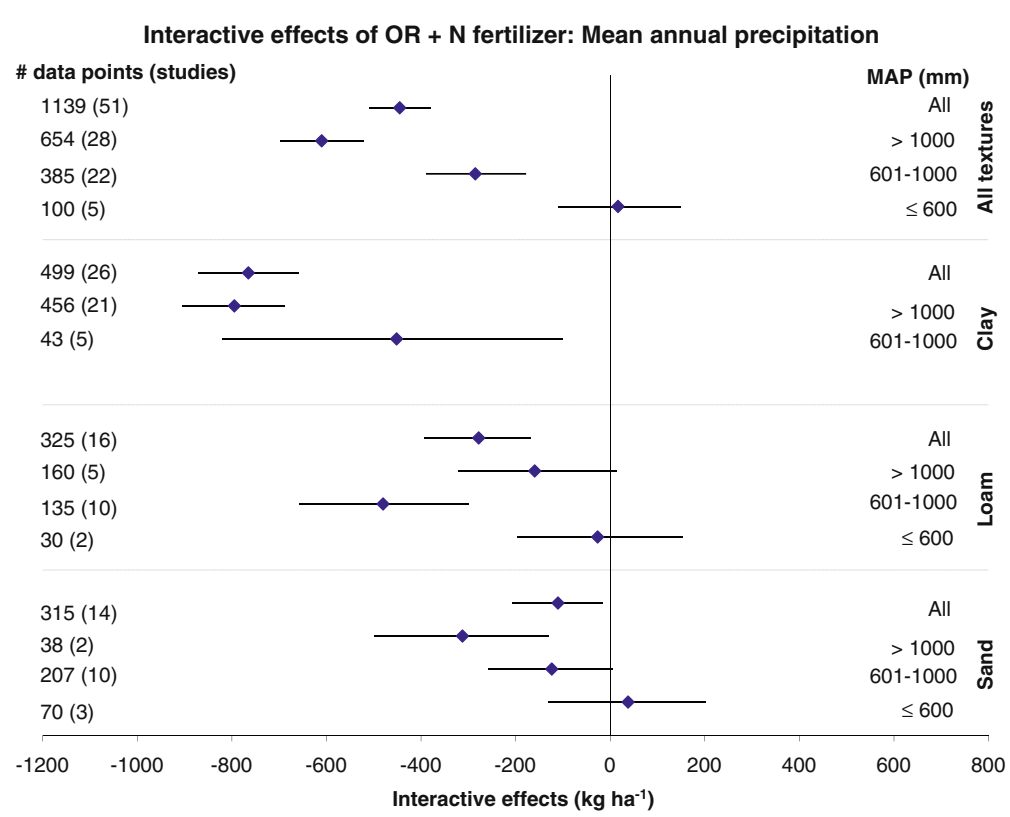

efficiencies in clayey soils; $20 \mathrm{~kg}$ grain increase $\mathrm{kg}^{-1} \mathrm{~N}$ applied compared to 7 and $10 \mathrm{~kg}$ grain increase $\mathrm{kg}^{-1} \mathrm{~N}$ applied to loamy and sandy soils, respectively (Figs. 10 and 11). The greatest agronomic $\mathrm{N}$ use efficiency of 27 and $37 \mathrm{~kg}$ grain increase $\mathrm{kg}^{-1} \mathrm{~N}$ added was observed in clayey soils when $\leq 30 \mathrm{kgNha}^{-1}$ was added as OR-N and fertilizer-N, respectively (Fig. 11a and b). In comparison, in coarser textured soils agronomic $\mathrm{N}$ use efficiency was less than 13 and $20 \mathrm{~kg}$ grain increase $\mathrm{kg}^{-1} \mathrm{~N}$ added where $\leq 30 \mathrm{kgNha}^{-1}$ was added as OR-N and fertilizer-N, respectively (Fig. 11a and b).

\section{Soil organic carbon}

The addition of ORs, both alone and in combination with $\mathrm{N}$ fertilizers resulted in SOC contents that were $17 \%$ and $12 \%$ greater than the no input control, respectively (Fig. 12a). Although, there were no differences in SOC responses over the control between sole ORs and ORs $+\mathrm{N}$ fertilizers, the ORs $+\mathrm{N}$ fertilizers treatment tended to result in lower SOC than sole ORs (Fig. 12a). The sole addition of $\mathrm{N}$ fertilizers resulted in SOC contents that were not significantly different from the control but was significantly less than when ORs were added alone (Fig. 12a). There was a general trend of increasing SOC responses with increasing OR-N quantities; greater SOC responses were observed in treatments where $>30 \mathrm{~kg}$ OR-Nha ${ }^{-1}$ was added while experiments where $\leq 30 \mathrm{~kg}$ OR-Nha ${ }^{-1}$ was added were not different from the control (Fig. 12b). Soil organic C responses following the application of sole ORs was greater in sandy soils and least in loamy soils (Fig. 12c).

\section{Discussion}

Maize yield responses

\section{Benefits of external nutrients}

Results from our meta-analysis clearly highlight the positive maize yield benefits realized following the external addition of nutrients in SSA soils in the following decreasing order; ORs $+\mathrm{N}$ fertilizers $>\mathrm{N}$ fertilizers $>$ ORs (Fig. 2a). While the addition of $\mathrm{N}$ fertilizers has been shown to result in greater crop yields than ORs (Baggs et al. 2000; Bremer and van Kessel 1992; Ladd and Amato 1986), greater crop yields have been observed following the combined application of ORs with $\mathrm{N}$ fertilizers (Kimani et al. 2007; Kramer et al. 2002; Mtambanengwe et al. 2006). The greater yield benefits with the combined treatment have been mainly attributed to the direct interactions between the two resources where temporary immobilization of $\mathrm{N}$ from fertilizers by ORs may result in improved synchrony between supply and 
Fig. 9 Interactive effects of the combined addition of organic resources (OR) with mineral $\mathrm{N}$ fertilizers categorized into a four OR quality classes (See Table 1), and b OR-N quantities for clayey, loamy and sandy soils. Interactive effects $\left(\mathrm{kgha}^{-1}\right)$ are expressed as unweighted averages with $95 \%$ confidence intervals represented by error bars. Numbers of effect size comparisons are given as \# of data points and number of studies from which the points are taken appear in parentheses a

Interactive effects of $\mathrm{OR}+\mathrm{N}$ fertilizer: $\mathrm{OR}$ quality

\# data points (studies)

1139 (51)

$251(18)$

$259(21)$

$545(35)$

$84(4)$

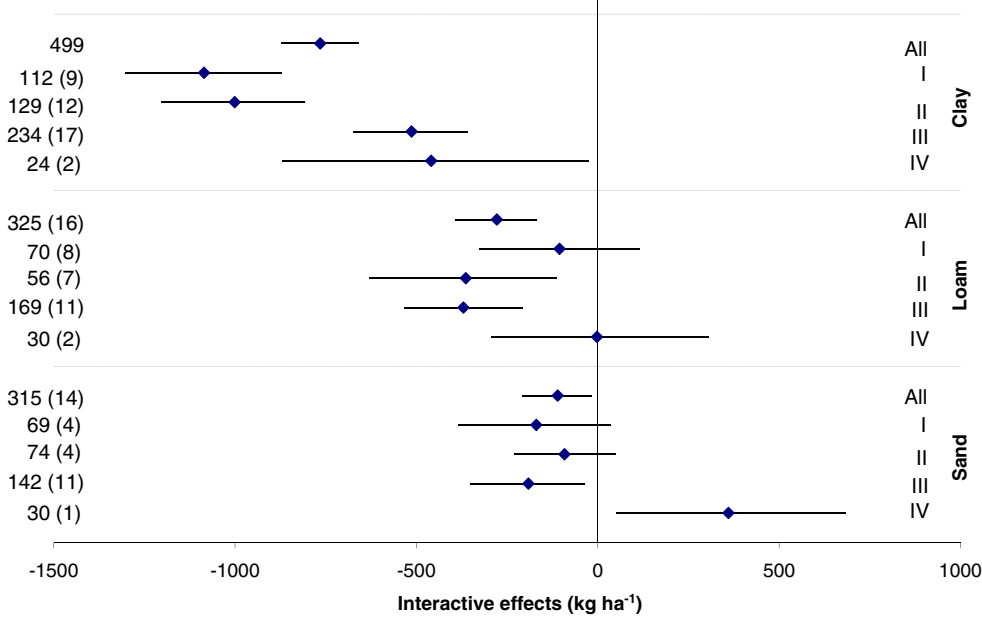

b

Interactive effects of OR + N fertilizer: OR-N quantity

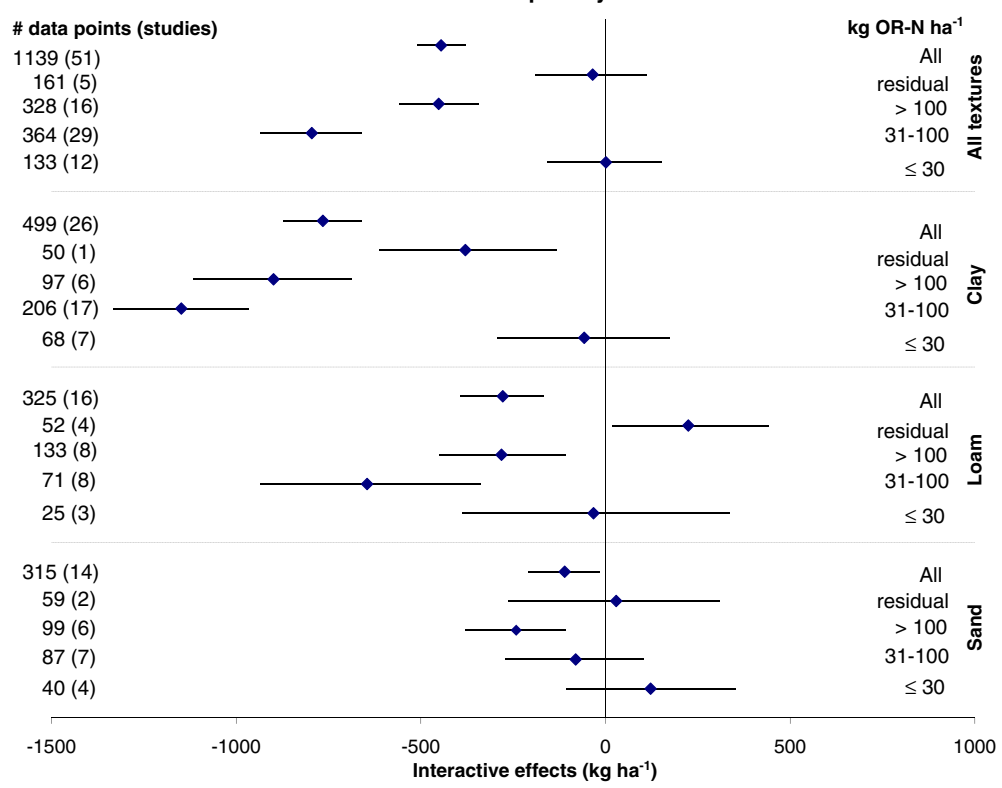

demand of nutrients (Myers et al. 1994; Palm et al. 2001a; Vanlauwe et al. 2001c). This improved synchrony enhances the use efficiency of the two resources, often leading to positive interactive effects on yield, i.e. yields greater than the sum of yields obtained following the sole application of either resource (Vanlauwe et al. 2001a). The positive interactive effects might also be due to the alleviation of other growth limiting factors such as micronutrients (Palm et al. 1997; Zingore et al. 2008). However, in our analysis across all studies, the interactive effects of combining the two resources were, most often, negative (Figs. 8 and 9). Moreover, the agronomic $\mathrm{N}$ use efficiency following the combined addition of ORs and $\mathrm{N}$ fertilizers was not different from sole applied ORs but was instead lower 
Fig. 10 Nitrogen use efficiency of the combined addition of organic resources (OR) with mineral $\mathrm{N}$ fertilizers categorized into four OR quality classes (See Table 1) for the clayey, loamy and sandy soils. Nitrogen use efficiency (kg grain increase over the control kg ${ }^{-1} \mathrm{~N}$ applied) expressed as unweighted averages with $95 \%$ confidence intervals represented by error bars. Numbers of effect size comparisons are given as \# of data points and number of studies from which the points are taken appear in parentheses

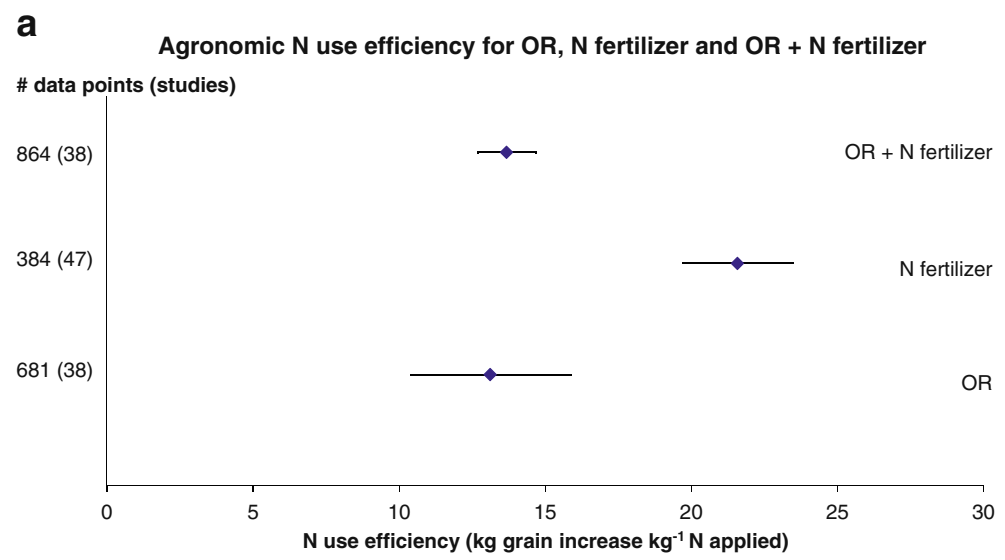

b

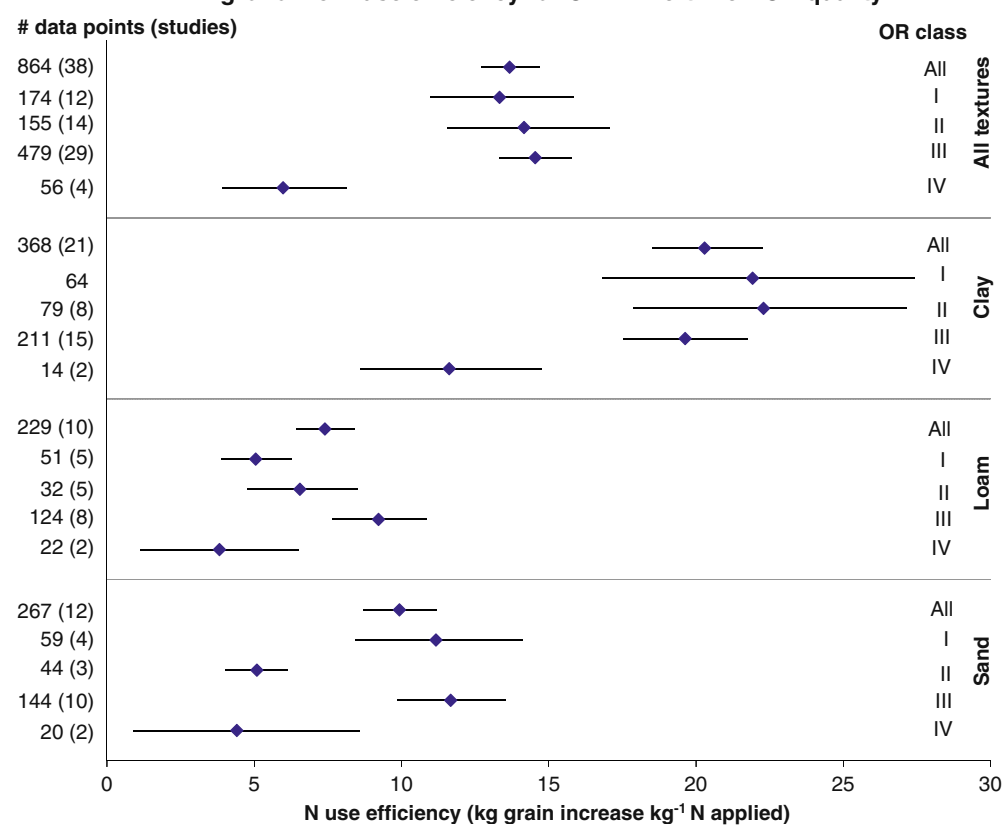

than sole applied $\mathrm{N}$ fertilizers (Fig. 10a). This indicates that the extra yields observed with the combined treatment were not caused by improved efficiency of utilization when the two resources are added together, but likely due to the extra $\mathrm{N}$ supplied when the two resources were added together. However, excess amounts of $\mathrm{N}$ were added in the combined treatment where at least $100 \mathrm{kgNha}^{-1}$ was added in the combined treatment in more than $70 \%$ of the studies (data not shown) with sum $\mathrm{N}$ added as high as $667 \mathrm{kgNha}^{-1}$. This could have reduced the agronomic $\mathrm{N}$ use efficiency (Cassman et al. 2002) and masked the possible positive interactions. Nonethe- less, it should be noted that yield responses were variable under different conditions; for example different OR qualities led to different interactive effects in different textured soils while low quantities of $\mathrm{N}$ added resulted in greater agronomic $\mathrm{N}$ use efficiencies (see sections below).

While results from our meta-analysis imply no improvement in agronomic $\mathrm{N}$ use efficiency following the combined addition of ORs with $\mathrm{N}$ fertilizers compared to sole applied ORs or $\mathrm{N}$ fertilizers, there is a possible shift towards increased $\mathrm{N}$ utilization efficiency of the two resources in the long-term. Previous studies have shown lower recoveries of OR 
Fig. 11 Nitrogen use efficiency of the combined addition of organic resources (OR) with mineral $\mathrm{N}$ fertilizers categorized into a OR-N and, b fertilizer-N quantity classes (See Table 1) for the clayey, loamy and sandy soils. Nitrogen use efficiency (kg grain increase over the control kg ${ }^{-1} \mathrm{~N}$ applied) expressed as unweighted averages with $95 \%$ confidence intervals represented by error bars. Numbers of effect size comparisons are given as \# of data points and number of studies from which the points are taken appear in parentheses a

Agronomic $\mathrm{N}$ use efficiency for $\mathrm{OR}+\mathrm{N}$ fertilizer: OR-N quantity

\# data points (studies)

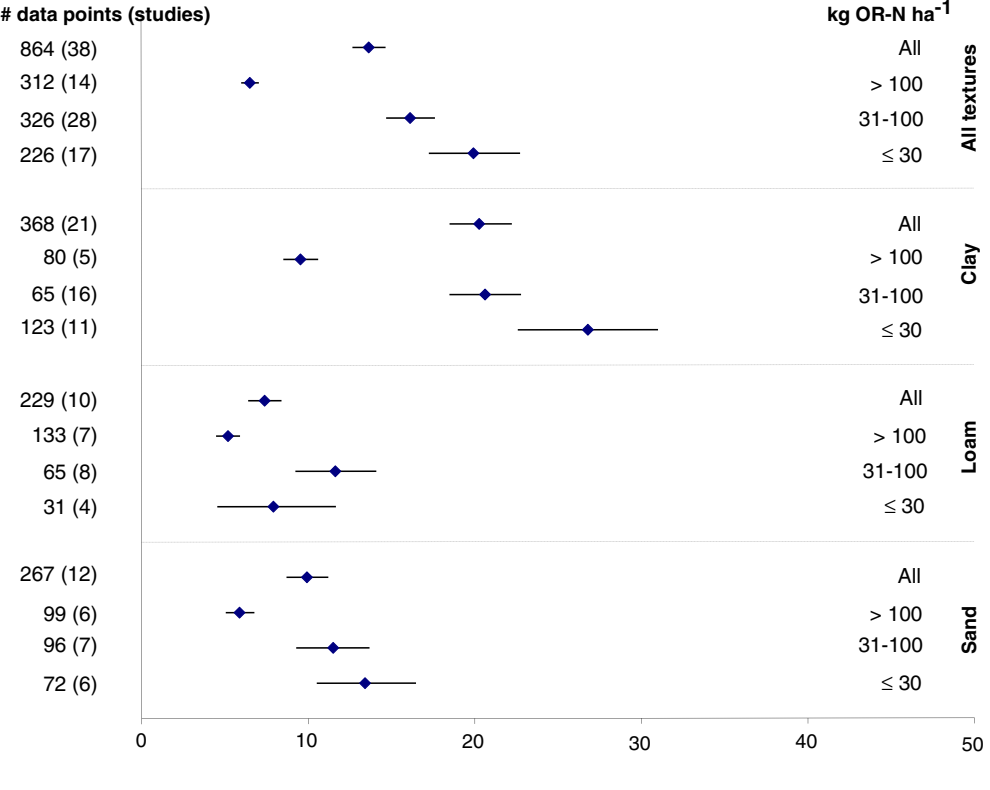

$\mathrm{N}$ use efficiency (kg grain increase $\mathrm{kg}^{-1} \mathrm{~N}$ applied)

\section{b}

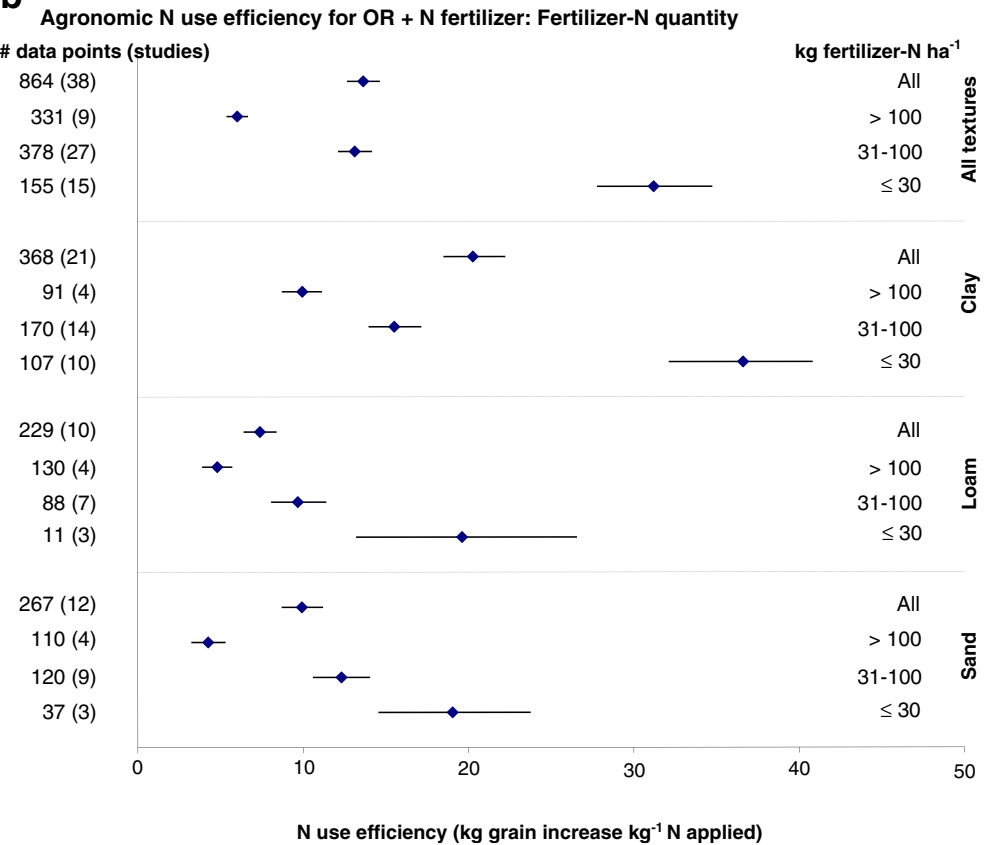

applied $\mathrm{N}$ in the first year of application compared to $\mathrm{N}$ fertilizers but with greater residual benefits than $\mathrm{N}$ fertilizers in subsequent seasons (Bosshard et al. 2009; Cadisch et al. 1998; Handayanto et al. 1997). We also observed residual OR benefits on average crop yield response of $40 \%$ for sole applied ORs compared to the control, implying possible build-up of nutrients in soil following the application of ORs (Fig. 6a). Moreover, the addition of ORs, alone or in combination with $\mathrm{N}$ fertilizers resulted in greater SOC increases compared to the control whereas SOC following $\mathrm{N}$ fertilizer additions was not different from 

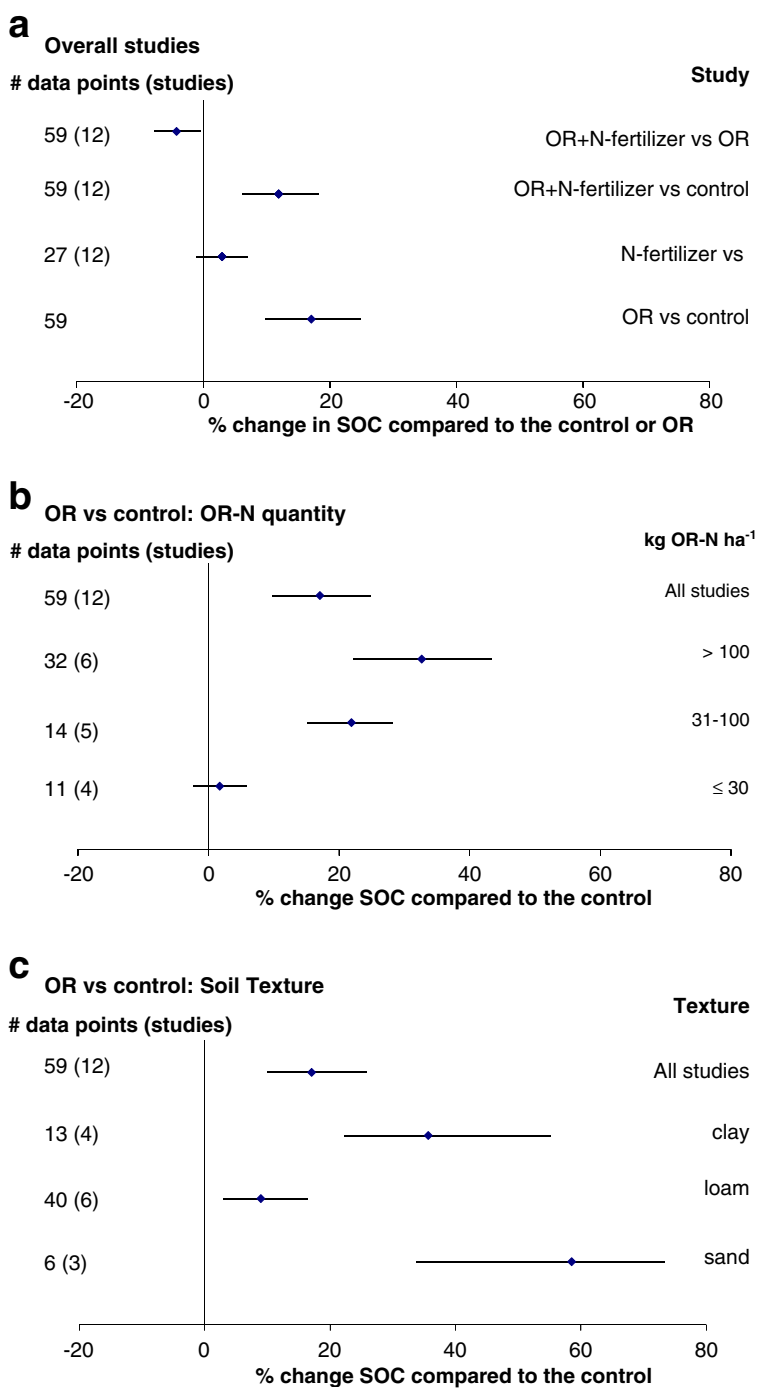

Fig. 12 a Soil organic $\mathrm{C}$ (SOC) responses to the addition of organic resources $(\mathrm{OR})$, mineral $\mathrm{N}$ fertilizers, or $\mathrm{OR}+\mathrm{N}$ fertilizer compared to the control. The combined treatment $(\mathrm{OR}+\mathrm{N}$ fertilizer) is also compared to sole applied OR $(\mathrm{OR}+\mathrm{N}$ fertilizer vs $\mathrm{OR})$. b SOC responses to the addition of OR compared to the no input control, categorized into three OR-N quantities. c SOC responses to the addition of OR compared to the no input control, categorized into three soil textural classes. SOC responses are expressed as average response percentage with $95 \%$ confidence intervals represented by the error bars. Numbers of effect size comparisons are given as \# of data points and number of studies from which the points are taken appear in parentheses

the control (Fig. 12a). Greater sustainability and soil organic matter build-up in the long-term following the addition of ORs, alone and in combination with $\mathrm{N}$ fertilizers (Bhattacharyya et al. 2007; Bhattacharyya et al. 2008; Bi et al. 2009) also imply greater crop yields may be achieved by these treatments than sole applied $\mathrm{N}$ fertilizers over time. Most of the studies (48) included in our meta-analysis were carried out over less than $5 \mathrm{yr}$, with 16 of them being carried out over one season. Thus, although there were lower agronomic $\mathrm{N}$ use efficiencies and negative interactive effects following the combined addition of ORs with $\mathrm{N}$ fertilizers in the short-term, there are possible improvements on these in the long-term. This brings a need to invest in long-term evaluations of the combined addition of ORs with $\mathrm{N}$ fertilizers in SSA.

\section{Organic resource quality and $O R-N$ quantity influences}

Generally, greater OR-N quantities were added with high quality ORs than low quality ORs thus the greater yield responses with high quality ORs were likely due to greater amounts of $\mathrm{N}$ added (Figs 4). In support, several studies have observed greater crop yields with high than low rates of OR application (Chivenge et al. 2009; Mtambanengwe and Mapfumo 2006). Similarly, greater yields have been observed with high than low quality ORs (Mtambanengwe et al. 2006; Murwira et al. 2002; Teklay et al. 2006; Vanlauwe et al. 2001c). The addition of high quality ORs, class I, results in a fast release of nutrients, which may be taken up by plants if they are in synchrony with crop demands (Kimetu et al. 2004; Mafongoya et al. 1998a; Palm et al. 2001b). In contrast, the addition of intermediate to low quality ORs, classes III and IV ORs, may cause $\mathrm{N}$ immobilization and, therefore, lead to lower yields than the no input control (Kapkiyai et al. 1999; Mugwira and Murwira 1997; Sakala et al. 2000). In our metaanalysis, although low quality ORs, class IV, resulted in lower crop yield responses than other OR quality classes, the decline in crop yields with class IV ORs compared to the control was only observed in sandy soils (Fig. 4a), probably reflecting the inherent infertility of sandy soils (Bationo et al. 2007; Grant 1981). This was supported by the low yields of the control and the greater yield responses following the external addition of nutrients in sandy soils compared to other textures (Fig. 1). Although the addition of low quality ORs would have been anticipated to increase moisture retention and availability (Bationo et al. 2007; Bauer and Black 1992; Tian et al. 2007; Vanlauwe et al. 2002a), nutrient limitations may have 
been more critical for crop growth (Greenwood et al. 1996; Ouédraogo et al. 2006) and probably more so in sandy soils where the nutrient base is low. Nonetheless, differences among OR quality and OR-N quantity classes were more distinct in the clayey soils (Fig. 4b) and this was probably because of the greater contact between OR and clay particles (Gentile et al. 2008; Mary et al. 1996). Clay particles have a large surface area, enhancing microbial contact with ORs whereas the limited contact in coarse textured soils may limit OR decomposition (Strong et al. 1999). Additionally, coarse textured soils have a lower moisture holding capacity which may also limit decomposition of ORs (Manning et al. 2008), and thus result in less distinct OR quality differences compared to fine textured soils. Moreover, soil aggregate and SOC dynamics in clayey soils are influenced by OR quality and in turn influence OR decomposition and nutrient dynamics whereas in coarser textured soils there are fewer aggregates (Bossuyt et al. 2001; Six et al. 2001).

Although OR quality was clearly important in influencing maize yield, there were generally no differences in maize yield responses, agronomic $\mathrm{N}$ use efficiency and interactive effects between OR classes I and II when applied alone or in combination with $\mathrm{N}$ fertilizers in all soils (Figs. 4, 5, 6, 9 and 10). This suggests that polyphenol content, which separates the two classes (Mafongoya et al. 1998a; Oglesby and Fownes 1992; Palm et al. 2001a), may not play a significant role in nutrient release under field conditions. While polyphenols have been shown to be biochemically recalcitrant and, therefore reduce $\mathrm{N}$ mineralization (Heal et al. 1997; Mafongoya et al. 1998b; Palm and Sanchez 1991), Vanlauwe et al. (2001b) showed that polyphenol contents influenced maize $\mathrm{N}$ uptake in a pot trial, but its impact was minimal under field conditions. Similarly, N mineralization (Basamba et al. 2007; Gentile et al. 2008; Teklay and Malmer 2004) and crop yields (Chivenge et al. 2009; Kimetu et al. 2004; Shisanya et al. 2009) have been observed to be similar for the two OR classes, probably because in some instances the polyphenols are leached out of the soil (Vanlauwe et al. 2002b). Additionally, recent studies have shown that biochemical recalcitrance may not be as long lasting as initially thought (Gentile et al. 2008; Grandy and Neff 2008; Marschner et al. 2008) but that OR decomposition is primarily driven by OR-N content (Parton et al. 2007).
Thus, contrary to the decision support system proposed by Palm et al. (2001a, 1997) where they separated classes I and II ORs, we conclude that there are no differences in maize yield responses between the two classes. The current meta-analysis suggests three distinct OR classes with classes I and II falling in the high quality class, classes III and IV in the intermediate and low quality classes, respectively (Figs. 4a, 5a and 9a). Similarly, Vanlauwe et al. (2005b) showed three distinct quality classes based on short-term $\mathrm{N}$ mineralization assays.

When the ORs $+\mathrm{N}$ fertilizer treatment was compared to sole ORs, greater yield responses were observed with low quality ORs than high quality ORs (Fig. 7a). This was probably because greater yields were observed with sole high quality ORs (Fig. 4a) such that the supplementary addition of $\mathrm{N}$ fertilizers resulted in a small increase in maize yields. On the contrary, low quality ORs may have induced $\mathrm{N}$ limitations that were alleviated by the addition of fertilizer-N resulting in greater yield increases compared to sole ORs. This alleviation was more pronounced in sandy soils where the addition of $\mathrm{N}$ fertilizers to class IV ORs resulted in maize yield responses of $249 \%$ when compared to sole ORs, whereas in clayey soils it was only $35 \%$ with the same OR class (Fig. 7a). Several studies have also observed greater increases with the combined application of low than high quality OR over sole OR (Friesen et al. 2002; Teklay et al. 2006; Vanlauwe et al. 2002a). Similarly, Mtambanengwe et al. (2006) observed a mere $13 \%$ yield increase when class I OR, C. juncea, was added in combination with $\mathrm{N}$ fertilizer compared to sole $C$. juncea in a sandy soil. In contrast, there was a $325 \%$ and $800 \%$ yield increase with the combined addition of class III and IV ORs with $\mathrm{N}$ fertilizers compared to sole ORs, respectively.

Positive interactive effects have been observed when intermediate and low quality ORs are applied in combination with $\mathrm{N}$ fertilizers but not with high quality ORs (Vanlauwe et al. 2002a, 2005a). Thus, we expected positive interactive effects with class III and IV ORs but these were only observed with class IV ORs and only in sandy soils (Fig. 9a). However, when class IV ORs $+\mathrm{N}$ fertilizers were compared to sole $\mathrm{N}$ fertilizers, there were no yield responses for all soil textures (Fig. 7b). In addition, agronomic $\mathrm{N}$ use efficiency for the combined addition of class IV ORs with $\mathrm{N}$ fertilizers was less 
than 5 compared to $12 \mathrm{~kg}$ grain increase $\mathrm{kg}^{-1} \mathrm{~N}$ added with class III ORs in sandy soils (Fig. 10). Thus, in support of the decision support system (Palm et al. 1997; 2001a), where fertilizers are available, there are no added benefits of combining their application with class IV ORs.

In contrast to comparisons with sole ORs, when the combined treatment was compared to sole $\mathrm{N}$ fertilizers, yield responses increased with increasing OR quality (Fig. 7b). While there were no differences between OR classes I and II in sandy and loamy soils, in clayey soils class II ORs $+\mathrm{N}$ fertilizers resulted in a yield response of $25 \%$ over $\mathrm{N}$ fertilizers compared to $11 \%$ with class I ORs (Fig. 7b). This suggests that the combined addition of $\mathrm{N}$ fertilizers with class II ORs may be more beneficial than with class I ORs, as proposed by Palm et al. (2001a; 1997) but only in clayey soils. However, the interactive effects of combining class II ORs with $\mathrm{N}$ fertilizers were generally negative and not different from class I ORs (Fig. 9a). Additionally, the agronomic $\mathrm{N}$ use efficiencies were not different for the two classes in clayey soils but were greater with class I ORs than class II ORs in sandy soils (Fig. 10).

Residual effects of ORs were also influenced by OR quality with greater residual effects observed with high quality ORs, both when ORs were applied alone or in combination with $\mathrm{N}$ fertilizers (Fig. 6). This contradicts the general consensus that low quality ORs may have greater residual benefits due to the slow decomposition of ORs making nutrients available over longer periods of time (Mafongoya et al. 1998a, 1997; Palm et al. 2001b; Tian et al. 2007). However, given that OR-N added by the low quality ORs was less than that added by high quality ORs, it is possible that there were just not enough nutrients to be used by the following crop. The lack of residual effects in sandy soils indicates the need to continuously add nutrients to these inherently infertile soils (Bationo et al. 2007). However, while there were no residual effects of ORs in sandy soils, the addition of $\mathrm{N}$ fertilizers in the residual year resulted in crop yield responses of about $80 \%$ over the control whereas in clayey soils residual effects were $49 \%$ and $63 \%$ over the control for ORs and ORs $+\mathrm{N}$ fertilizers. These results stress the need to continuously add nutrients in the inherently infertile sandy soils and suggest that the addition of ORs in sandy soils may lead to improved water use efficiency once nutrients are added.
Fertilizer-N and OR-N quantities and soil fertility influences

The greater yield responses to $\mathrm{N}$ fertilizer additions observed in experiments where $\leq 30 \mathrm{kgNha}^{-1}$ was added (Fig. 3a) were likely because most of the studies with this low fertilizer- $\mathrm{N}$ addition rate were in areas receiving $\leq 600 \mathrm{~mm}$ rainfall annually. As shown in the analyses, greater yield responses were observed in studies done in low rainfall areas (Fig. 3a). When considering the yield differences, it was clear that the absolute yield increases due to addition of $\leq 30 \mathrm{kgNha}^{-1}$ were lowest among the $\mathrm{N}$ application classes (Fig. 3b). Furthermore, absolute yield increases were lowest in climates receiving $\leq 600 \mathrm{~mm}$ MAP (Fig. 3b). Thus, similar to previous observations (Vanlauwe et al. 2001c), proportional yield responses to nutrient additions (ORs, $\mathrm{N}$ fertilizers, ORs $+\mathrm{N}$ fertilizers) were greater when the initial control yields were low and vice versa (Fig. 1).

The efficiency of utilization of applied $\mathrm{N}$ fertilizers was greater when lower quantities of $\mathrm{N}$ fertilizers were applied and decreased with increasing fertilizer$\mathrm{N}$ quantities (Fig. 11b). Lower agronomic $\mathrm{N}$ use efficiencies have been observed with greater quantities of fertilizer-N added (Cassman et al. 2002; OrtizMonasterio et al. 1997; Raun et al. 2002). Thus, the lower agronomic $\mathrm{N}$ use efficiencies observed with the combined addition of ORs $+\mathrm{N}$ fertilizers than sole $\mathrm{N}$ fertilizers were likely because of greater quantities of $\mathrm{N}$ that were generally added with the combined treatment compared to sole $\mathrm{N}$ fertilizers. However, the same was not observed when the combined treatment was compared to sole ORs where generally lower quantities of $\mathrm{N}$ were added compared to the combined treatment (Fig. 10a). The lack of differences in agronomic $\mathrm{N}$ use efficiencies between sole applied ORs and the combined treatment imply that ORs may reduce the efficiency of $\mathrm{N}$ fertilizers, similar to observations by Takahashi et al. (2007) where the agronomic $\mathrm{N}$ use efficiencies of $\mathrm{N}$ fertilizers were reduced when applied with compost. Although reduced $\mathrm{N}$ losses and improved $\mathrm{N}$ synchrony have been proposed to lead to increased $\mathrm{N}$ use efficiencies following the combined application of ORs $+\mathrm{N}$ fertilizers (Giller 2002; Palm et al. 2001a; Vanlauwe et al. 2002a), in the current meta-analysis there was no evidence of increased $\mathrm{N}$ use efficiencies when ORs were combined with $\mathrm{N}$ fertilizers. It is worth noting 
that, agronomic $\mathrm{N}$ use efficiencies were greater where lower amounts of $\mathrm{N}$ were added, both as OR-N and fertilizer-N, but were greater for low fertilizer-N than OR-N. This was particularly more so in clayey soils where agronomic $\mathrm{N}$ use efficiency was 27 and $37 \mathrm{~kg}$ grain increase $\mathrm{kg}^{-1} \mathrm{~N}$ added when $\leq 30 \mathrm{~kg}$ OR-Nha ${ }^{-1}$ was added as OR-N and fertilizer $\mathrm{N}$, respectively (Fig. 11a and b). Thus, while low quantities of $\mathrm{N}$ as $\mathrm{OR}-\mathrm{N}$ and fertilizer-N enhance utilization efficiency of added $\mathrm{N}$, clayey soils tended to also promote greater efficiency of $\mathrm{N}$ utilization. Clayey soils are generally more fertile with greater SOC than coarser textured soils, influencing the efficiency of $\mathrm{N}$ utilization. In support, greater agronomic $\mathrm{N}$ use efficiencies have been observed in fertile soils close the homestead than those that are further from the homestead and less fertile (Vanlauwe et al. 2010b, 2006).

\section{Soil organic carbon responses}

The increases in SOC with ORs and ORs $+\mathrm{N}$ fertilizers and not with sole $\mathrm{N}$ fertilizers show the need for OR additions to increase SOC (Fig. 12a). Similar to yield responses, greater differences in SOC were observed in sandy soils than in clayey and loamy soils (Fig. 12c). This was most likely because of the low starting SOC contents such that the addition of ORs caused greater proportional increases in SOC, which, in absolute terms may be lower than in finer textured soils. In addition, because of the lower protection of added ORs and faster loss of nutrients in sandy soils than clayey soils, there is a need for continuous addition of $\mathrm{C}$ in sandy soils (Mapfumo et al. 2007). Chivenge et al. (2007) observed greater responses in SOC contents following the addition of mulch in a sandy soil while there were insignificant responses in a clayey soil. Although there were greater yield increases with OR + $\mathrm{N}$ fertilizer compared to sole OR (Fig. 2a), there were greater $\mathrm{C}$ contents with sole $\mathrm{OR}$ than $\mathrm{OR}+\mathrm{N}$ fertilizer (Fig. 12). This is likely because the added $\mathrm{N}$ fertilizers enhanced decomposition of the added OR, which likely resulted in greater $\mathrm{N}$ supply but also greater losses of added C (Khan et al. 2007; Nardi et al. 2004). In contrast, Bhattacharyya et al. (2007) observed greater SOC with ORs $+\mathrm{N}$ fertilizers than ORs, whereas Nayak et al. (2009) found no differences in SOC between sole applied ORs and ORs $+\mathrm{N}$ fertilizers. Nevertheless, Nayak et al. (2009) observed greater microbial biomass $\mathrm{C}$ and $\mathrm{N}$, and active SOC with ORs $+\mathrm{N}$ fertilizers than ORs.

Greater yield responses with sole $\mathrm{N}$ fertilizer than OR probably also led to greater belowground $\mathrm{C}$ inputs in the sole $\mathrm{N}$ fertilizer (Fig. 2), but $\mathrm{N}$ fertilizers applied alone did not increase SOC (Fig. 12a). Similarly, Gentile et al. (2010) and Khan et al. (2007) observed greater SOC contents in treatments where OR was added than when $\mathrm{N}$ fertilizer was added. In contrast, Goyal et al. (1992) found that the addition of $\mathrm{N}$ and $\mathrm{P}$ fertilizers resulted in increased SOC contents. In their study, they also observed greater SOC contents following the combined application of OR and $\mathrm{N}$ fertilizers and this was mainly attributed to increased root growth associated with greater organic matter inputs. Studies that compared above- versus belowground $\mathrm{C}$ input to soil generally find a greater stabilization of root-derived $\mathrm{C}$ than residue-derived C (Denef and Six 2006; Gale and Cambardella 2000; Gale et al. 2000; Six et al. 2002). Nevertheless, our results further emphasize the need of adding $\mathrm{C}$ inputs in order to build up and/or maintain SOC, especially in sandy soils.

\section{Conclusions}

Given that the studies included in the meta-analysis were carried out across most agro-ecological zones in SSA and across different soil textures using a wide range of OR qualities, we can confidently conclude that yield responses are largely dependent on addition of nutrients, soil texture and MAP. While OR quality clearly influences crop yield responses, the use of polyphenol content to separate classes I and II seems to be of less importance under field conditions. Organic resource $\mathrm{N}$ content and total quantities of OR-N added, just like total fertilizer-N added, are more influential on crop yields than polyphenol contents. Yield responses were greater following the combined application of ORs with $\mathrm{N}$ fertilizers compared to the addition of either resource alone. However, the dominance of negative interactive effects and lack of differences in agronomic $\mathrm{N}$ use efficiencies with ORs applied alone but lower than $\mathrm{N}$ fertilizers applied alone imply that the extra increase in grain yield is mostly related to the extra $\mathrm{N}$ added and not to an increase in efficiency of utilization by applying the resources together. However, given that total $\mathrm{N}$ added in the combined treatment was $\geq 100 \mathrm{kgNha}-1$ in $70 \%$ of the observations, possible interactive effects could have 
been masked with reduced resource utilization efficiency. Utilization efficiency of combining ORs with $\mathrm{N}$ fertilizers were greater when lower quantities of OR-N and fertilizer-N were added, suggesting that this may be the most appropriate strategy for managing the resources, particularly in sandy soils. Absolute yield responses were greater in finer textured soils and high MAP areas, but the proportional increases to nutrient additions were greater in low MAP areas and coarse textured soils. Therefore, positive interactive effects were observed when low quality OR was incorporated in sandy soils. Furthermore, there were no residual effects of sole ORs in sandy soils on yield, showing the need to continuously add $\mathrm{N}$ fertilizers in these soils. In addition, the application of ORs increased SOC, and this was more so in sandy soils, and thus offers, in combination with $\mathrm{N}$ fertilizer additions, the potential for the improvement of soil quality, crop productivity and its sustainability in SSA.

Acknowledgements This study was funded by the National Science Foundation, Ecosystem Cluster (DEB: 0344971). We are also grateful to F. Mtambangwe, P. Mapfumo and N. Nhamo for sharing their data; K. J. van Groenigen and M.A. de Graaf for their advice on statistical procedures.

Open Access This article is distributed under the terms of the Creative Commons Attribution Noncommercial License which permits any noncommercial use, distribution, and reproduction in any medium, provided the original author(s) and source are credited.

\section{Appendix 1}

Table 3 List of publications included in the meta-analysis

\begin{tabular}{|c|c|c|c|c|c|}
\hline Author & Source & Country & Organic resources & $\begin{array}{l}\# \\
\text { Sites }\end{array}$ & Seasons \\
\hline Akinnifesi et al. (2007) & $\begin{array}{l}\text { Plant \& Soil 294: } \\
\text { 203-207 }\end{array}$ & Malawi & Gliricidium sepium & 1 & 4 \\
\hline Akulumuka et al. (1996) & $\begin{array}{l}\text { CIMMYT 5th Maize } \\
\text { Conf, 146-148 }\end{array}$ & Tanzania & Farmyard manure (fym) & 2 & 1 \\
\hline Ayuk and Mafongoya (2001) & $\begin{array}{l}\text { SADC/ICRAF 14th } \\
\text { S Africa Proc }\end{array}$ & Zambia & $\begin{array}{l}\text { Farmyard manure, } \\
\text { Tephrosia vogelii, } \\
\text { Sesbania sesban }\end{array}$ & 1 & 2 \\
\hline Bado et al. (2004) & $\begin{array}{l}\text { AFNET TSBF-CIAT } \\
\text { Proc, } 77-87\end{array}$ & Burkina Faso & Fym & 2 & 7 \\
\hline Baijukya et al. (2005) & Nut Cycl 73: 75-87 & Tanzania & $\begin{array}{l}\text { Grass fallow, fym, } \\
\text { Crotalaria juncea }\end{array}$ & 1 & 1 \\
\hline Carsky et al. (1999) & Nut Cycl 55: 95-105 & Nigeria & $\begin{array}{c}\text { Mucuna pruriens, } C \text {. juncea, } \\
\text { lablab, Vigna unguiculata } \\
\text { (cowpea), grass fallow }\end{array}$ & 2 & 1 \\
\hline Chikowo et al. (2003) & DPhil dissertation & Zimbabwe & Fym & 1 & 1 \\
\hline Chikowo et al. (2004) & Plant \& Soil 262: 303-315 & Zimbabwe & $\begin{array}{l}\text { Acacia angustisima, } \\
\text { S. sesban, Cajanus cajun, } \\
\text { grass fallow }\end{array}$ & 1 & 2 \\
\hline Chilimba et al. (2004) & $\begin{array}{l}\text { CIMMYT Working } \\
\text { Paper No. } 11\end{array}$ & Malawi & Compost, fym & 2 & 1 \\
\hline Chivenge et al. (2009) & $\begin{array}{c}\text { Agron J. 101: } \\
\text { 1266-1275 }\end{array}$ & Kenya & $\begin{array}{l}\text { Tithonia diversifolia, } \\
\text { Calliandra calothyrsus, } \\
\text { Zea mays (maize), } \\
\text { sawdust, fym }\end{array}$ & 2 & 10 \\
\hline Delve et al. (2004) & $\begin{array}{l}\text { AFNET TSBF-CIAT } \\
\text { Proc, } 127-136\end{array}$ & Kenya & T. diversifolia & 1 & 2 \\
\hline Fofana et al. (2005) & $\begin{array}{c}\text { Nut Cycl 71: } \\
\text { 227-237 }\end{array}$ & Togo & M. pruriens & 2 & 4 \\
\hline Franke et al. (2008) & $\begin{array}{c}\text { Nut Cycl 82: } \\
117-135\end{array}$ & Nigeria & $\begin{array}{l}\text { Pueraria phaseoloides, } \\
\text { Stylosanthes guianensis, } \\
\text { Glycine max, Aeschynomene } \\
\text { histrix, cowpea }\end{array}$ & 2 & 3 \\
\hline Gigou et al. (2002) & $\begin{array}{l}\text { INM in SSA, } \\
\text { CABI, 199-208 }\end{array}$ & Cote d'Ivoire & Compost & 1 & 20 \\
\hline Gikonyo and Smithson (2004) & $\begin{array}{l}\text { AFNET TSBF-CIAT } \\
\text { Proc, } 137-149\end{array}$ & Kenya & Fym & 1 & 1 \\
\hline
\end{tabular}


Table 3 (continued)

\begin{tabular}{|c|c|c|c|c|c|}
\hline Author & Source & Country & Organic resources & $\begin{array}{l}\# \\
\text { Sites }\end{array}$ & Seasons \\
\hline Goma (2003) & $\begin{array}{l}\text { Soil Fert. Mgt Africa, } \\
\text { CIAT, pp 187-218 }\end{array}$ & Zambia & $\begin{array}{l}\text { Leucaena leucocephala, } \\
\text { G. sepium, Ficus macrophylla, } \\
\text { fym }\end{array}$ & 1 & 1 \\
\hline Horst and Hardter 1994 & $\begin{array}{l}\text { Plant \& Soil 160: } \\
\text { 171-183 }\end{array}$ & Ghana & Cowpea & 1 & 2 \\
\hline Ikerra et al. (1998) & $\begin{array}{l}\text { CIMMYT 6th Maize } \\
\text { Conf Proc, 226-231 }\end{array}$ & Malawi & G. sepium & 1 & 2 \\
\hline Itimu et al. (1998) & $\begin{array}{l}\text { CIMMYT Soil Fert Mal } \\
\text { \& Zim, 203-207 }\end{array}$ & Malawi & Senna spectabilis, G. sepium & 1 & 1 \\
\hline Iwuafor et al. (2002) & $\begin{array}{l}\text { INM in SSA, CABI, } \\
\quad 185-198\end{array}$ & $\begin{array}{r}\text { Nigeria, } \\
\text { Benin }\end{array}$ & Organic matter, Zea mays, fym & 3 & 2 \\
\hline Jones et al. (1997) & Driven by Nature, CABI & Malawi & L. leucocephala, G. sepium & 1 & 2 \\
\hline Kapkiyai et al. (1999) & $\begin{array}{l}\text { Soil Biol Biochem 31: } \\
\text { 1773-1782 }\end{array}$ & Kenya & Zea mays, fym & 1 & 1 \\
\hline Kihanda et al. (1998) & $\begin{array}{l}\text { CIMMYT 6th Maize } \\
\text { Conf Proc, } 250-252\end{array}$ & Kenya & Fym & 1 & 1 \\
\hline Kimani and Lekasi (2004) & $\begin{array}{l}\text { AFNET TSBF-CIAT } \\
\text { Proc, } 187-206\end{array}$ & Kenya & Fym & 1 & 1 \\
\hline Kimani et al. (2007) & $\begin{array}{l}\text { Advances in ISFM in SSA, } \\
353-358\end{array}$ & Kenya & $\begin{array}{l}\text { T. diversifolia, } M . \text { pruriens, } \\
\text { C. juncea, lablab, compost, fym, Zea } \\
\text { mays }\end{array}$ & 3 & 1 \\
\hline Kimaro et al. (2009) & $\begin{array}{l}\text { Agric Ecosyst Environ 134: } \\
\quad 115-125\end{array}$ & Tanzania & C. Cajun, fym & 1 & 2 \\
\hline Kimetu et al. (2004) & Nut Cycl 68: 127-135 & Kenya & $\begin{array}{l}\text { T. diversifolia, Senna siamea, } \\
\text { C. calothyrsus }\end{array}$ & 1 & 2 \\
\hline Kumwenda et al. (1998) & $\begin{array}{l}\text { CIMMYT Soil Fert Mal } \\
\text { \& Zim, } 85-86\end{array}$ & Malawi & C. cajun, C. juncea, M. pruriens & 1 & 2 \\
\hline Kwesiga et al. (1999) & $\begin{array}{l}\text { Agroforest Syst 47: } \\
\quad 49-66\end{array}$ & Zambia & S. sesban & 1 & 5 \\
\hline $\begin{array}{l}\text { Mafongoya and Dzowela } \\
\text { (1999) }\end{array}$ & $\begin{array}{l}\text { Agroforest Syst 47: } \\
\text { 139-151 }\end{array}$ & Zimbabwe & $\begin{array}{l}\text { A. anguistisima, C. cajun, } \\
\text { S. sesban }\end{array}$ & 1 & 2 \\
\hline Mafongoya et al. (2006) & Nutr Cycl 76:137-151 & Zambia & S. sesban & 1 & 3 \\
\hline Makumba et al. (2001) & $\begin{array}{l}\text { SADC/ICRAF 14th } \\
\text { S Africa Proc }\end{array}$ & Malawi & G. sepium & 1 & 2 \\
\hline Mariki et al. (1996) & $\begin{array}{l}\text { CIMMYT 5th Maize } \\
\text { Conf, 200-201 }\end{array}$ & Tanzania & Zea mays & 1 & 2 \\
\hline Mochoge and Onwonga (1998) & $\begin{array}{l}\text { CIMMYT 6th Maize } \\
\text { Conf Proc, } 267-270\end{array}$ & Kenya & V. unguiculata & 6 & 1 \\
\hline Mtambanengwe et al. (2006) & Nut Cycl 76: 271-284 & Zimbabwe & $\begin{array}{l}\text { C. juncea, C. calothyrsus, } \\
\text { Zea mays, sawdust, fym }\end{array}$ & 2 & 5 \\
\hline Mucheru-Muna et al. (2004) & $\begin{array}{l}\text { FORMAT OR Mgt } \\
\text { in Kenya }\end{array}$ & Kenya & $\begin{array}{l}\text { C. juncea, M. pruriens, } \\
\text { C. calothyrsus, L. leucocephala, } \\
\text { T. diversifolia, fym }\end{array}$ & 2 & 4 \\
\hline Mugendi et al. (1999) & $\begin{array}{l}\text { Agroforest Syst 46: } \\
\quad 30-50\end{array}$ & Kenya & C. calothyrsus, L.leucocephala & 1 & 1 \\
\hline Mugwe et al. (2007) & $\begin{array}{l}\text { African Crop Sci J 15: } \\
\text { 111-126 }\end{array}$ & Kenya & $\begin{array}{l}\text { M. pruriens, C. ochloleuca, } \\
\text { T. diversifolia, C. calothyrsus, } \\
\text { Leucaena trichandra, } \\
\text { cattle manure }\end{array}$ & 1 & 4 \\
\hline Mugwira and Murwira (1997) & $\begin{array}{l}\text { CIMMYT Soil Fert Net working } \\
\text { paper } \\
\text { no. } 2,18 \mathrm{pp}\end{array}$ & Zimbabwe & Fym & 1 & \\
\hline Mungai et al. (1998) & $\begin{array}{l}\text { CIMMYT 6th Maize } \\
\text { Conf Proc, } 253-255\end{array}$ & Kenya & T. Diversifolia, Zea mays & 2 & 1 \\
\hline Murwira et al. (1998) & $\begin{array}{l}\text { CIMMYT Soil Fert Mal } \\
\text { \& Zim, 179-182 }\end{array}$ & Zimbabwe & Fym & 6 & 1 \\
\hline Nhamo (2002) & MPhil thesis & Zimbabwe & Fym & 11 & 2 \\
\hline Nyadzi et al. (2006) & $\begin{array}{l}\text { Agric Ecosyst Environ } \\
\text { 116: } 93-103\end{array}$ & Tanzania & $\begin{array}{l}\text { A. crassicarpa, A. julifera, } \\
\text { A. leptocarpa, L. pallida, } \\
\text { S. siamea, grass fallow }\end{array}$ & 1 & 1 \\
\hline Nyamangara et al. (2003) & $\begin{array}{l}\text { African Crop Sci J 11: } \\
\text { 289-300 }\end{array}$ & Zimbabwe & Cattle manure & 1 & 2 \\
\hline
\end{tabular}


Table 3 (continued)

\begin{tabular}{|c|c|c|c|c|c|}
\hline Author & Source & Country & Organic resources & $\begin{array}{l}\# \\
\text { Sites }\end{array}$ & Seasons \\
\hline Nyathi et al. (1995) & $\begin{array}{l}\text { African Crop Sci J. 3: } \\
\quad 451-456\end{array}$ & Zimbabwe & $\begin{array}{l}\text { Brachystegia spiciformis, } \\
\text { L. leucocephala, fym }\end{array}$ & 1 & 1 \\
\hline Nziguheba et al. (2004) & $\begin{array}{l}\text { AFNET TSBF-CIAT } \\
\text { Proc, } 329-346\end{array}$ & Kenya & T. diversifolia & 1 & 4 \\
\hline Nziguheba et al. (2009) & $\begin{array}{l}\text { Plant Soil 314: } \\
\quad 143-157\end{array}$ & $\begin{array}{r}\text { Nigeria, } \\
\text { Benin }\end{array}$ & & & \\
\hline Okalebo et al. (2004) & $\begin{array}{l}\text { AFNET TSBF-CIAT } \\
\text { Proc, } 359-372\end{array}$ & Kenya & Triticum aestivum, G. $\max$ & 1 & 4 \\
\hline Onyango et al. (1998) & $\begin{array}{l}\text { CIMMYT 6th Maize } \\
\text { Conf Proc, } 242-246\end{array}$ & Kenya & Fym, compost & 4 & 3 \\
\hline Sakala et al. (2000) & DARS Annual Proc & Malawi & C. juncea, M. pruriens, lablab & 1 & 1 \\
\hline Snapp et al. (1998) & $\begin{array}{l}\text { Ag Ecosyst Environ 71: } \\
\text { 185-200 }\end{array}$ & Zimbabwe & Arachis hypogea & 1 & 1 \\
\hline Swift et al. (1994) & $\begin{array}{l}\text { Rothamsted Long-term } \\
\text { Exp Proc, CABI, } \\
\text { 229-251 }\end{array}$ & Kenya & Farmyard manure & 1 & 15 \\
\hline Teklay et al. (2006) & Nut Cycl 75: 163-173 & Ethiopia & Albizia, Cordia, Milletia, Crotia & 1 & 2 \\
\hline Vanlauwe et al. (2005a) & $\begin{array}{l}\text { Plant \& Soil 273: } \\
\text { 337-337-354 }\end{array}$ & Nigeria & L. leucocephala, S. siamea & 1 & 17 \\
\hline Vanlauwe (unpublished) & Unpublished & Kenya & $\begin{array}{l}\text { T. diversifolia, C. calothyrsus, } \\
\text { Zea mays, sawdust, fym }\end{array}$ & 2 & 1 \\
\hline Workayehu and Kena (1998) & $\begin{array}{l}\text { CIMMYT 6th Maize } \\
\text { Conf Proc, } 271-273\end{array}$ & Ethiopia & Coffea arabica (coffee) & 1 & 3 \\
\hline Yeboah (unpublished) & Unpublished & Ghana & $\begin{array}{l}\text { C. juncea, L. leucocephala, } \\
\text { sawdust, Zea mays, fym }\end{array}$ & 2 & 5 \\
\hline
\end{tabular}

\section{References}

Ainsworth EA, Rosenburg MS, Wang X (2007) Meta-analysis: the past, present and future. New Phytol 176:752-745

Akinnifesi F, Makumba W, Sileshi G, Ajayi O, Mweta D, (2007) Synergistic effect of inorganic N and P fertilizers and organic inputs from Gliricidia sepium on productivity of intercropped maize in Southern Malawi. Plant Soil 294: 203-217

Akulumuka V, Mduruma Z, Kaswende J, Nkonya E (1996) Factors influencing maize seed recycling and other implications to hybrids. In: Ransom JK, Palmer AFE, Zambezi BT, Mduruma ZO, Waddington SR, Pixely KV, Jewell DC (Eds), Maize Productivity Gains Through Research and Technology Dissemination, Proceedings of the Fifth Eastern and Southern Africa Regional Maize Conference, Arusha, Tanzania pp 146-148

Ayuk ET, Mafongoya PL (2001) Risk and returns of improved fallows in Eastern Zambia: an application of a stochastic dominance method. In: Kwesiga F, Ayuk E, Agumya A (Eds). Proceedings of the 14th Southern African Regional Review and Planning Workshop, Harare, Zimbabwe pp 2834

Bado BV, Sedogo MP, Lompo F (2004) Long term effects of mineral fertilizers, phosphate rock, dolomite and manure on the characteristics of an Ultisol and maize yield in Burkina Faso. In: Bationo A (Ed), Managing Nutrient Cycles to Sustain Soil Fertility in Sub-Saharan Africa, Academy of Science Publishers, Nairobi, Kenya pp 77-87
Baggs EM, Watson CA, Rees RM (2000) The fate of nitrogen from incorporated cover crop and green manure residues. Nutr Cycl Agroecosyst 56:153-163

Baijukya FP, de Ridder N, Giller KE (2005) Managing Legume Cover Crops and their Residues to Enhance Productivity of Degraded Soils in the Humid Tropics: A Case Study in Bukoba District, Tanzania. Nutr Cycl Agroecosyst 73:75-87

Basamba T, Barrios E, Singh B, Rao I (2007) Impact of planted fallows and a crop rotation on nitrogen mineralization and phosphorus and organic matter fractions on a Colombian volcanic-ash soil. Nutr Cycl Agroecosyst 77:127-141

Bationo A, Vanlauwe B, Abdoulaye MS, Adamou A, Kimetu J, Kihara J, Tabo R, Koala S (2005) Increasing land sustainability and productivity through soil fertility management in the West-African Sudano-Sahelian zone. In: Nutrient and Water Management Practices for Increasing Crop Production in Rainfed Arid/Semi-Arid Areas, Proceedings of a coordinated research project. International Atomic Energy Agency, Vienna, Austria IAEA-TECDOC-1468

Bationo A, Hartemink AE, Lungo O, Naimi M, Okoth P, Smaling EMA, Thiombiano L (2006) African soils: their productivity and profitability of fertilizer use: background paper for the African Fertilizer Summit 9-13th June 2006, Abuja, Nigeria. IFDC

Bationo A, Kihara J, Vanlauwe B, Waswa B, Kimetu J (2007) Soil organic carbon dynamics, functions and management in West African agro-ecosystems. Agric Syst 94:13-25

Bauer A, Black AL (1992) Organic carbon effects on available water capacity of three soil textural groups. Soil Sci Soc Am J 56:248-254 
Bhattacharyya R, Chandra S, Singh RD, Kundu S, Srivastva AK, Gupta HS (2007) Long-term farmyard manure application effects on properties of a silty clay loam soil under irrigated wheat-soybean rotation. Soil Till Res 94:386-396

Bhattacharyya R, Kundu S, Prakash V, Gupta HS (2008) Sustainability under combined application of mineral and organic fertilizers in a rainfed soybean-wheat system of the Indian Himalayas. Eur J Agron 28:33-46

Bi L, Zhang B, Liu G, Li Z, Liu Y, Ye C, Yu X, Lai T, Zhang J, Yin $J$ et al (2009) Long-term effects of organic amendments on the rice yields for double rice cropping systems in subtropical China. Agric Ecosyst Environ 129:534-541

Bosshard C, Sørensen P, Frossard E, Dubois D, Mäder P, Nanzer S, Oberson A (2009) Nitrogen use efficiency of 15 $\mathrm{N}$-labelled sheep manure and mineral fertiliser applied to microplots in long-term organic and conventional cropping systems. Nutr Cycl Agroecosyst 83:271-287

Bossuyt H, Denef K, Six J, Frey SD, Merckx R, Paustian K (2001) Influence of microbial populations and residue quality on aggregate stability. Appl Soil Ecol 16:195-208

Bremer E, van Kessel C (1992) Plant-available nitrogen from lentil and wheat residues during a subsequent growing season. Soil Sci Soc Am J 56:1155-1160

Cadisch G, Handayanto E, Malama C, Seyni F, Giller KE (1998) $\mathrm{N}$ recovery from $\mathrm{N}$ prunnings and priming effects are governed by the residue quality. Plant Soil 205:125-134

Carsky RJ, Oyewole B, Tian G (1999) Integrated soil management for the savanna zone of W. Africa: legume rotation and fertilizer N. Nutr Cycl Agroecosyst 55:95-105

Cassman KG, Peng S, Olk DC, Ladha JK, Reichardt W, Dobermann A, Singh U (1998) Opportunities for increased nitrogen-use efficiency from improved resource management in irrigated rice systems. Field Crops Res 56:7-39

Cassman KG, Dobermann A, Walters DT (2002) Agroecosystems, nitrogen-use efficiency, and nitrogen management. AMBIO 31:132-140

Chikowo R (2003) Nitrogen cycling in agroecosystems of subhumid Zimbabwe: closing the loop. PhD Dissertation, Wageningen University, Netherlands

Chikowo R, Mapfumo P, Nyamugafata P, Giller, KE (2004) Woody legume fallow productivity, biological N2-fixation and residual benefits to two successive maize crops in Zimbabwe. Plant Soil 262: 303-315

Chilimba ADC, Sakala WD, Kabambe VH (2004) The effects of different organic fertilizers and their interactions with inorganic fertilizers on maize yields. CMMYT Working Paper No. 11

Chivenge P (2008) Exploring mechanisms by which organic and mineral nutrient sources regulate nutrient cycling. $\mathrm{PhD}$ Dissertation, University of California, Davis, USA

Chivenge PP, Murwira HK, Giller KE, Mapfumo P, Six J (2007) Long-term impact of reduced tillage and residue management on soil carbon stabilization: implications for conservation agriculture on contrasting soil. Soil Till Res 94:328-337

Chivenge P, Vanlauwe B, Gentile R, Wangechi H, Mugendi D, van Kessel C, Six J (2009) Organic and mineral input management to enhance crop productivity in Central Kenya. Agron J 101:1266-1275

Cobo JG, Dercon G, Cadisch G (2010) Nutrient balances in African land use systems across different spatial scales: a review of approaches, challenges and progress. Agric Ecosyst Environ 136:1-15

Constantinides M, Fownes JH (1994) Nitrogen mineralization from leaves and litter of tropical plants: relationship to nitrogen, lignin and soluble polyphenol concentrations. Soil Biol Biochem 26:49-55

Crawford E, Jayne T (2010) The World Bank Alternative Approaches for Promoting Fertilizer Use in Africa. Agriculture and Rural Development Discussion Paper 22, Washington DC, $69 \mathrm{pp}$

de Graaff MA, van Groenigen KJ, Six J, Hungate B, van Kessel C (2006) Interactions between plant growth and soil nutrient cycling under elevated $\mathrm{CO}$ 2: a meta-analysis. Glob Chang Biol 12:2077-2091

Delve RJ (2004) Combating nutrient depletion in East Africathe work of the SWNM program. In: Bationo A (Ed), Managing Nutrient Cycles to Sustain Soil Fertility in SubSaharan Africa, Academy of Science Publishers, Nairobi, Kenya pp 127-136

Denef K, Six J (2006) Contributions of incorporated residue and living roots to aggregate-associated and microbial carbon in two soils with different clay mineralogy. Eur J Soil Sci 57:774-786

Feller C, Beare MH (1997) Physical control of soil organic matter dynamics in the tropics. Geoderma 79:69-116

Fischer G, Van Velthuizen HT, Nachtergaele FO (2001) Global agro-ecological zones assessment for agriculture in the 21 st century. Vienna, Austria and FAO, Rome

Fofana B, Tamelokpo A, Wopereis MCS, Breman H, Dzotsi K, Carsky RJ (2005) Nitrogen use efficiency by maize as affected by a mucuna short fallow and $\mathrm{P}$ application in the coastal savanna of West Africa. Nutr Cycl Agroecosyst 71:227-237

Franke A, Laberge G, Oyewole B, Schulz S (2008) A comparison between legume technologies and fallow, and their effects on maize and soil traits, in two distinct environments of the West African savannah. Nutr Cycl Agroecosyst 82: 117-135

Friesen DK, Assenga R, Bogale T, Mmbaga TE, Kikafunda J, Negassa A, Ojiem J, Onyango R (2002) Grain legumes and green manures in East African maize systems- an overview of ECAMAW Network Research. In: Waddington SR (Ed), Grain Legumes and Green Manures for Soil Fertility in Southern Africa: Taking Stock of Progress. Proceedings of Soil Fert Net Conference, 8-11 October 2002 Vumba, Zimbabwe, pp 113-118

Gale WJ, Cambardella CA (2000) Carbon dynamics of surface residue- and root-derived organic matter under simulated no-till. Soil Sci Soc Am J 64:190-195

Gale WJ, Cambardella CA, Bailey TB (2000) Surface residueand root-derived carbon in stable and unstable aggregates. Soil Sci Soc Am J 64:196-201

Gentile R, Vanlauwe B, Chivenge P, Six J (2008) Interactive effects from combining fertilizer and organic residue inputs on nitrogen transformations. Soil Biol Biochem 40:2375-2384

Gentile R, Vanlauwe B, Kavoo A, Chivenge P, Six J (2010) Residue quality and $\mathrm{N}$ fertilizer do not influence aggregate stabilization of $\mathrm{C}$ and $\mathrm{N}$ in two tropical soils with contrasting texture. Nutr Cycl Agroecosyst 88:121131 
Gigou J, Bredoumy SK (2002) Yield trends, soil nitrogen and organic matter content during 20 years of continuous maize cultivation. In: Vanlauwe B, Diels J, Sanginga N, Merckx R (Eds), Integrated Plant Nutrient Management in sub-Saharan Africa: From Concept to Practice CABI Publishing, pp 199-208

Gikonyo EW, Smithson PC (2004) Effects of farmyard manure, potassium and their combinations on maize yields in the high and medium rainfall areas of Kenya. In: Bationo A (Ed), Managing Nutrient Cycles to Sustain Soil Fertility in Sub-Saharan Africa, Academy of Science Publishers, Nairobi, Kenya pp 137-150

Giller KE (2002) Targeting management of organic resources and mineral fertilizers: can we match scientists' fantasies with farmers' realities? In: Vanlauwe B, Diels K, Sanginga $\mathrm{N}$, Merckx R (eds) Integrared plant nutrient management in Sub-Saharan Africa: from concept to practice. CAB International, Wallingford, pp 155-171

Giller KE, Cadisch G (1995) Future benefits from biological nitrogen fixation: an ecological approach to agriculture. Plant Soil 174:255-277

Giller KE, Cadisch G, Mugwira LM (1998) Potential benefits from interactions between mineral and organic nutrient sources. In: Waddington SR et al (eds) Soil fertility research for maize-based farming systems in Malawi and Zimbabwe. Soil Fertility Network and CIMMYT-Zimbabwe, Harare, pp $155-158$

Goma HC (2003) Potential for changing traditional soil fertility management systems in the wet miombo woodlands of Zambia: the chitemene and fundikila systems. In: Gichuru MP, Bationo A, Bekunda MA, Goma HC, Mafongoya PL, Mugendi DN, Murwira HK, Nandwa SM, Nyathi P, Swift MJ (Eds), Soil Fertility Management: A Regional Perspective, pp 187-218

Goyal S, Mishra MM, Hooda IS, Singh R (1992) Organic matter-microbial biomass relationships in field experiments under tropical conditions: Effects of inorganic fertilization and organic amendments. Soil Biol Biochem 24:1081-1084

Grandy AS, Neff JC (2008) Molecular C dynamics downstream: the biochemical decomposition sequence and its impact on soil organic matter structure and function. Sci Total Environ 404:297-307

Grant P (1981) The fertility of sandy soils in peasant agriculture. Zimb Agric J 78:168-175

Greenwood DJ, Rahn C, Draycott A, Vaidyanathan LV, Paterson C (1996) Modelling and measurement of the effects of fertilizer-N and crop residue incorporation on $\mathrm{N}$-dynamics in vegetable cropping. Soil Use Manage 12:13-24

Gurevitch J, Hedges LV (1999) Statistical issues in ecological meta-analyses. Ecology 80:1142-1149

Gurevitch J, Morrison JA, Hedges LV (2000) The interactions between competition and predation: a meta-analysis of field experiments. Am Nat 155:435-453

Handayanto E, Giller KE, Cadisch G (1997) Regulating N release from legume tree prunings by mixing residues of different quality. Soil Biol Biochem 29:1417-1426

Heal OW, Anderson JM, Swift MJ (1997) Plant litter quality and decomposition: an historical overview. In: Cadisch G, Giller KE (eds) Driven by nature. Plant litter quality and decomposition. CAB International, Wallinford, pp 3-30
Horst W, Hardter R (1994) Rotation of maize with cowpea improves yield and nutrient use of maize compared to maize monocropping in an alfisol in the northern Guinea Savanna of Ghana. Plant Soil, 160:171-183

Hungate BA, K-Jv G, Six J, Jastrow JD, Luo Y, de Graaff M-A, van Kessel C, Osenberg CW (2009) Assessing the effect of elevated carbon dioxide on soil carbon: a comparison of four meta-analyses. Glob Chang Biol 15:2020-2034

Ikerra ST, Smithson PC, Maghembe JA, Buresh RJ (1998) Soil nitrogen dynamics and maize yields in a Gliricidia sepium-maize intercrop in southern Malawi. In: Maize Production Technology for the Future: Challenges and Opportunities, Proceedings of the sixth Eastern and Southern Africa Regional Maize Conference, Addis Ababa, Ethiopia, pp 226-231

Itimu OA, Jones RB, Cadisch G, Giller KE (1998) Are the interactions between organic and mineral $\mathrm{N}$ sources? Evidence from field experiments in Malawi. In: Waddington SR, Murwira HK, Kumwenda JDT, Hikwa D, Tagwira F (Eds), Soil Fertility Research for Maizebased Systems in Malawi and Zimbabwe, Proceedings of the Soil Fertility Network, Results and Planning, Mutare, Harare, pp 203-207

Iwuafor ENO, Aihou K, Jaryum JS, Vanlauwe B, Diels J, Sanginga N, Lyasse O, Deckers J, Merckx R (2002) Onfarm evaluation of the contribution of sole and mixed applications of organic matter and urea to maize grain production in the savanna. In: Vanlauwe B, Diels J, Sanginga N, Merckx R (Eds), Integrated Plant Nutrient Management in sub- Saharan Africa: From Concept to Practice CABI Publishing, pp 185-198

Jones, RB, Snapp SS, Phombeya HSK (1997) Management of leguminous leaf residues to improve nutrient use efficiency in the sub-humid tropics. In: Cadisch G, Giller K (Eds), Driven by Nature, CABI, pp 239-251

Kapkiyai JJ, Karanja NK, Qureshi JN, Smithson PC, Woomer PL (1999) Soil organic matter and nutrient dynamics in a Kenyan nitisol under long-term fertilizer and organic input management. Soil Biol Biochem 31:1773-1782

Khan SA, Mulvaney RL, Ellsworth TR, Boast CW (2007) The myth of nitrogen fertilization for soil carbon sequestration. J Environ Qual 36:1821-1832

Kihanda FM, Wood M, O’Neill MK (1998) Effect of lime, farmyard manure and NP fertilizers on maize yield and soil chemical characteristics in an ando-humic nitisol of central Kenya. In: Maize Production Technology for the Future: Challenges and Opportunities, Proceedings of the sixth Eastern and Southern Africa Regional Maize Conference, Addis Ababa, Ethiopia, pp 250-252

Kimani SK, Lekasi JK (2004) Managing manures throughout their production cycle enhances their usefulness as fertilizers: A review. In A. Bationo (Ed.), Managing Nutrient Cycles to Sustain Soil Fertility in Sub-Saharan Africa (pp. 187-198). Nairobi, Kenya: Academy of Science Publishers

Kimani SK, Esilaba AO, Odera MM, Kimenye L, Vanlauwe B, Bationo A (2007) Effects of organic and mineral sources of nutrients on maize yields in three districts of central Kenya. In: Bationo A, Waswa B, Kihara J, Kimetu J (Eds), Advances in Integrated Soil Fertility Research in subSaharan Africa: Challenges and Opportunities 
Kimaro AA, Timmer VR, Chamshama SAO, Ngaga YN, Kimaro DA (2009) Competition between maize and pigeonpea in semi-arid Tanzania: Effect on yields and nutrition of crops. Agric Ecosyst Environ, 134:115-125

Kimetu JM, Mugendi DN, Palm CA, Mutuo PK, Gachengo CN, Bationo A, Nandwa S, Kungu JB (2004) Nitrogen fertilizer equivalencies or organics of differing quality and optimum combination with inorganic nitrogen source in Central Kenya. Nutr Cycl Agroecosyst 68:127-135

Knorr M, Frey SD, Curtis PS (2005) Nitrogen additions and litter decomposition: a meta-analysis. Ecology 86:32523257

Koné A, Tondoh J, Angui P, Bernhard-Reversat F, LorangerMerciris G, Brunet D, Brédoumi S (2008) Is soil quality improvement by legume cover crops a function of the initial soil chemical characteristics? Nutr Cycl Agroecosyst 82:89105

Kramer AW, Doane TA, Horwath WR, van Kessel C (2002) Combining fertilizer and organic inputs to synchronize $\mathrm{N}$ supply in alternative cropping systems in California. Agric Ecosyst Environ 91:233-243

Kumwenda JDT, Gilbert R (1998) Biomass production by green manures on exhausted soils in Malawi: A soil fertility network trial. In: Waddington SR, Murwira HK, Kumwenda JDT, Hikwa D, Tagwira F (Eds), Soil Fertility Research for Maize-based Systems in Malawi and Zimbabwe, Proceedings of the Soil Fertility Network, Results and Planning, Mutare, Harare, pp 85-86

Kwesiga F, Franzel S, Place F, Phiri D, Simwanza C (1999) Sesbania sesban improved fallows in eastern Zambia: Their inception, development and farmer enthusiasm. Agrofor Syst, 47:49-66

Ladd JN, Amato M (1986) The fate of nitrogen from legume and fertilizer sources in soils successively cropped with wheat under field conditions. Soil Biol Biochem 18:417425

Lavelle P, Blanchart E, Martin A, Martin S, Spain A (1993) A hierarchical model for decomposition in terrestrial ecosystems: application to soils of the humid tropics. Biotropica 25:130-150

Mafongoya PL, Dzowela BH (1999) Biomass production of tree fallows and their residual effect on maize in Zimbabwe. Agrofor Syst, 47:139-151

Mafongoya PL, Nair PKR, Dzowela BH (1997) Multipurpose tree prunings as a source of nitrogen to maize under semiarid conditions in Zimbabwe. 3. Interactions of pruning quality and time of application on nitrogen recovery by maize in two soil types. Agrofor Syst 35:57-70

Mafongoya PL, Giller KE, Palm CA (1998a) Decomposition and nitrogen release patterns of tree prunings and litter. Agrofor Syst 38:77-97

Mafongoya PL, Nair PKR, Dzowela BH (1998b) Mineralization of nitrogen from decomposing leaves of multipurpose trees as affected by their chemical composition. Biol Fert Soils 27:143-148

Mafongoya P, Bationo A, Kihara J, Waswa B (2006) Appropriate technologies to replenish soil fertility in southern Africa. Nutr Cycl Agroecosyst, 76:137-151

Makumba WHI, Akinnifesi FK, Kwesiga FR (2001) Above and belowground performance Gliricidium sepium/Maize mixed cropping in Makoka, Malawi. In: Kwesiga F, Ayuk
E, Agumya A (Eds), Proceedings of the 14th Southern African Regional Review and Planning Workshop, Harare, Zimbabwe, pp 72-79

Manning P, Saunders M, Bardgett RD, Bonkowski M, Bradford MA, Ellis RJ, Kandeler E, Marhan S, Tscherko D (2008) Direct and indirect effects of nitrogen deposition on litter decomposition. Soil Biol Biochem 40:688-698

Mapfumo P, Mtambanengwe F, Vanlauwe B (2007) Organic matter quality and management effects on enrichment of soil organic matter fractions in contrasting soils in Zimbabwe. Plant Soil 296:137-150

Mariki WL, Akonaay HB, Mugedi LM (1996) The effects of crop residue (stover) on yield, soil structure and soil fertility. In: Ransom JK, Ransom JK, Palmer AFE, Zambezi BT, Mduruma ZO, Waddington SR, Pixely KV, Jewell DC (Eds), Maize Productivity Gains Through Research and Technology Dissemination. Proceedings of the Fifth Eastern and Southern Africa Regional Maize Conference, Arusha, Tanzania, pp 200-201

Marschner B, Brodowski S, Dreves A, Gleixner G, Gude A, Grootes PM, Hamer U, Heim A, Jandl G, Kaiser K et al (2008) How relevant is recalcitrance for the stabilization of organic matter in soils? J Plant Nutr Soil Sci 171:91-110

Mary B, Recous S, Darwis D, Robin D (1996) Interactions between decomposition of plant residues and nitrogen cycling in soil. Plant Soil 181:71-82

Melillo JM, Aber JD, Muratore JF (1982) Nitrogen and lignin control of hardwood leaf litter decomposition dynamics. Ecology 63:621-626

Miguez FE, Bollero GA (2005) Review of corn yield response under winter cover cropping systems using meta-analytic methods. Crop Sci 45:2318-2329

Mochoge BO, Onwanga RN (1998) Effect of cowpea intercrop on maize yield and nutrient use efficiency in the coastal lowlands and semi-arid parts of Kenya. In: Maize Production Technology for the Future: Challenges and Opportunities, Proceedings of the sixth Eastern and Southern Africa Regional Maize Conference, Addis Ababa, Ethiopia, pp 267-270

Morris M, Kelly VA, Kopicki RJ, Byerlee D (2007) Fertilizer use in African agriculture. Lessons learned and good practice guidelines. Directions in Development: Agriculture and Rural Development publication 39037 World Bank, Washington D C, $162 \mathrm{pp}$

Mtambanengwe F, Mapfumo P (2006) Effects of organic resource quality on soil profile $\mathrm{N}$ dynamics and maize yields on sandy soils in Zimbabwe. Plant Soil 281:173191

Mtambanengwe F, Mapfumo P, Vanlauwe B (2006) Comparative short-term effects of different quality organic resources on maize productivity under two different environments in Zimbabwe. Nutr Cycl Agroecosyst 76:271-284

Mucheru-Muna M, Mugendi D, Kangai R, Kung'u J, Mugwe J, Micheni A (2004) Organic resources for soil fertility management in Eastern Kenya. In: Savala CEN, Omare MN, Woomer PL (Eds), Organic Resources Management in Kenya: Perspectives and Guidelines, Nairobi, Kenya, pp 26-33

Mucheru-Muna M, Mugendi D, Kung'u J, Mugwe J, Bationo A (2007) Effects of organic and mineral fertilizer inputs on maize yield and soil chemical properties in a maize 
cropping system in Meru South District, Kenya. Agrofor Syst 69:189-197

Mugendi DN, Nair PKR, Mugwe JN, O'Neil MK, Woomer PL (1999) Alley cropping of maize with calliandra and leuceana in the subhumid highlands of Kenya. Part 1. Soil fertility changes and maize yield. Agrofor Syst, 46:39-50

Mugwe J, Mugendi D, Kungu J, Mucheru-Muna M (2007) Effect of plant biomass, manure and inorganic fertilizer on maize yield in the Central Highlands of Kenya. African Crop Sci J, 15:111-126

Mugwira LM (1984) Relative effectiveness of fertilizer and communal area manures as plant nutrient sources. Zimb Agric J 81:85-90

Mugwira LM, Murwira HK (1997) Use of Cattle manure to improve soil fertility in Zimbabwe: Past and current research and future research needs. Soil Fertility Network Research Results Working Paper No 2

Mungai NW, Kamau AW, Nacharia CN (1998) The effect of organic and inorganic phosphorus and time of split application of nitrogen on maize in Kenya. In: Maize Production Technology for the Future: Challenges and Opportunities, Proceedings of the sixth Eastern and Southern Africa Regional Maize Conference, Addis Ababa, Ethiopia, pp 253-255

Murwira HK, Tagwira F, Chikowo R, Waddington SR (1998) An evaluation of the agronomic effectiveness of low rates of cattle manure and combinations of inorganic $\mathrm{N}$ in Zimbabwe. In: Waddington SR, Murwira HK, Kumwenda JDT, Hikwa D, Tagwira F (Eds). Soil Fertility Research for Maize-based Systems in Malawi and Zimbabwe. Proceedings of the Soil Fertility Network, Results and Planning, Mutare, Harare, 7-11 July 1997 pp 179-182

Murwira HK, Mutuo P, Nhamo N, Marandu AF, Rabeson R, Mwale M, Palm CA (2002) Fertilizer equivalency values of organic materials of differing quality. In: Vanlauwe B, Diels J, Sanginga N, Merckx R (Eds), Integrated Plant Nutrient Management in sub-Saharan Africa: From Concept to Practice CABI Publishing, pp 113-122

Myers RJK, Palm CA, Cuevas E, Gunatilleke IUN, Brossard M (1994) The synchronization of nutrient mineralisation and plant nutrient demand. In: Woomer PL, Swift M (eds) The biological management of tropical soil fertility. Wiley, Chichester, pp 81-116

Nardi S, Morari F, Berti A, Tosoni M, Giardini L (2004) Soil organic matter properties after 40 years of different use of organic and mineral fertilisers. Eur J Agron 21:357-367

Nayak P, Patel D, Ramakrishnan B, Mishra A, Samantaray R (2009) Long-term application effects of chemical fertilizer and compost on soil carbon under intensive rice-rice cultivation. Nutr Cycl Agroecosyst 83:259-269

Nhamo N (2002) An evaluation of the efficacy of organic and inorganic fertilizer combinations in supplying nitrogen to crops. Master of Philosophy thesis, University of Zimbabwe

Nyadzi G, Janssen B, Oenema O (2006) Analysis of the effects of rotational woodlots on the nutrition and yield of maize following trees in western Tanzania. Agriculture, Ecosystems \& Environment, 116:93-103

Nyamangara J, Piha MI, Giller KE (2003) Effect of combined cattle manure and mineral nitrogen on maize $\mathrm{N}$ uptake and grain yield. African Crop Sci J, 11:289-300
Nyathi P, Campbell BM (1995) Interaction of tree leaf litter, manure and inorganic fertilizer on performance of maize in Zimbabwe. African Crop Sci J 3:451-456

Nziguheba G, Merckx R, Palm CA, Mutuo P (2002) Combining Tithonia diversifolia and fertilizers for maize production in a phosphorous deficient soil in Kenya. Agrofor Syst 55:165-174

Nziguheba G, Merckx R, Palm CA, Mutuo P (2004) Combined use of Tithonia diversifolia and inorganic fertilizers for improving maize production in Western Kenya. In: Bationo A (Ed), Managing Nutrient Cycles to Sustain Soil Fertility in Sub-Saharan Africa, Academy of Science Publishers, Nairobi, Kenya, pp 329-346

Nziguheba G, Tossah B, Diels J, Franke A, Aihou K, Iwuafor E, Nwoke C, Merckx R (2009) Assessment of nutrient deficiencies in maize in nutrient omission trials and long-term field experiments in the West African Savanna. Plant Soil 314:143157

Oglesby KA, Fownes JH (1992) Effects of chemical composition on nitrogen mineralization from green manures of seven tropical leguminous trees. Plant Soil 143:127-132

Oikeh SO, Kling JG, Okoruwa AE (1998) Nitrogen fertilizer management effects on maize grain quality in the West African moist Savanna. Crop Sci 38:1056-1161

Okalebo JR, Palm CA, Lekasi JK, Nandwa SM, Othieno CO, Waigwa M, et al. (2004) Use of organic and inorganic resources to increase maize yields in some Kenyan infertile soils: A five year experience. In: Bationo A (Ed), Managing Nutrient Cycles to Sustain Soil Fertility in Sub-Saharan Africa, Academy of Science Publishers, Nairobi, Kenya, pp 359-372

Onyango RMA, Mwangi TK, Kiiya WW, Kamidi MK (1998) Maintaining maize productivity by combining organic and inorganic fertilizers in small holder farms within the Kitale region. In: Maize Production Technology for the Future: Challenges and Opportunities, Proceedings of the sixth Eastern and Southern Africa Regional Maize Conference, Addis Ababa, Ethiopia, pp 242-246

Ortiz-Monasterio RJI, Sayre KD, Rajaram S, McMahon M (1997) Genetic progress in wheat yield and nitrogen use efficiency under four nitrogen rates. Crop Sci 37:898904

Ouédraogo E, Mando A, Brussaard L (2006) Soil macrofauna affect crop nitrogen and water use efficiencies in semi-arid West Africa. Eur J Soil Biol 42:S275-S277

Palm CA, Sanchez PA (1991) Nitrogen release from the leaves of some tropical legumes as affected by their lignin and polyphenolic contents. Soil Biol Biochem 23:83-88

Palm CA, Myers RJK, Nandwa SM (1997) Combined use of organic and inorganic nutrient sources for soil fertility maintenance and replenishment. In: Buresh RJ, Sanchez PA, Calhoun F (eds) Replenishing soil fertility in Africa SSSA Special publication No 51. American Society of Agronomy, Madison, pp 193-217

Palm CA, Gachengo CN, Delve RJ, Cadisch G, Giller KE (2001a) Organic inputs for soil fertility management in tropical agroecosystems: application of an organic resource database. Agric Ecosyst Environ 83:27-42

Palm CA, Giller KE, Mafongoya PL, Swift MJ (2001b) Management of organic matter in the tropics: translating theory into practice. Nutr Cycl Agroecosyst 61:63-75 
Parton W, Silver WL, Burke IC, Grassens L, Harmon ME, Currie WS, King JY, Adair EC, Brandt LA, Hart SC et al (2007) Global similarities on nitrogen release patterns during long-term decomposition. Science 315: 361-364

Raun WR, Solie JB, Johnson GV, Stone ML, Mullen RW, Freeman KW, Thomason WE, Lukina EV (2002) Improving nitrogen use efficiency in cereal grain production with optical sensing and variable rate application. Agron J 94:815-820

Rosenburg MS, Adams DC, Gurevitch J (2000) Metawin. Statistical Software for Meta-Analysis, Version 2. Sinauer Associates Inc, Sunderland, Massachusetts, USA

Rufino M, Dury J, Tittonell P, van Wijk M, Herrero M, Zingore S, Mapfumo P, Giller K. (2010) Competing use of organic resources, village-level interactions between farm types and climate variability in a communal area of $\mathrm{NE}$ Zimbabwe. Agric Syst, doi:10.1016/j.agsy.2010.01.001

Sakala W, Cadisch G, Giller KE (2000) Interactions between residues of maize and pigeonpea and mineral $\mathrm{N}$ fertilizers during decomposition and $\mathrm{N}$ mineralization. Soil Biol Biochem 32:679-688

Sanchez PA (2002) Soil fertility and hunger in Africa. Science 295:2019-2020

Shirazi MA, Boersma L (1984) A unifying quantitative analysis of soil texture. Soil Sci Soc Am J 48:142-147

Shisanya CA, Mucheru MW, Mugendi DN, Kung'u JB (2009) Effect of organic and inorganic nutrient sources on soil mineral nitrogen and maize yields in central highlands of Kenya. Soil Till Res 103:239-246

Sileshi G, Akinnifesi FK, Ajayi OC, Place F (2008) Metaanalysis of maize yield response to woody and herbaceous legumes in sub-Saharan Africa. Plant Soil 307:1-19

Six J, Carpentier A, van Kessel C, Merckx R, Harris D, Horwath WR, Luscher A (2001) Impact of elevated CO2 on soil organic matter dynamics as related to changes in aggregate turnover and residue quality. Plant Soil 234:27-36

Six J, Feller C, Denef K, Ogle SM, Sa MJC, Albrecht A (2002) Soil organic matter, biota and aggregation in temperate and tropical soils-Effects of no-tillage. Agronomie 22:755-775

Smaling EMA (2006) Fertilizer use and the environment in Africa: friends or foes? Background paper: African fertilizer summit: nourish the soil, feed the continent, 913 June 2006 Abuja, Nigeria, 25 pp

Smaling EMA, Nandwa S, Janssen BH (1997) Soil fertility in Africa is at stake. In: Buresh RJ, Sanchez PA, Calhoun F (Eds) Replenishing soil fertility in Africa. Soil Science Society of America (SSSA), SSSA Special Publication 51, Madison, pp 47-61

Snapp SS, Mafongoya PL, Waddington S (1998) Organic matter technologies for integrated nutrient management in smallholder cropping systems of southern Africa. Agric Ecosyst Environ, 71:185-200

Strong DT, Sale PWG, Helyar KR (1999) The influence of the soil matrix on nitrogen mineralisation and nitrification. IV a. Texture. Aust J Soil Res 37:329-344

Swift MJ, Seward PD, Frost PGH, Quresh JN, Muchena FN (1994) Long-term experiments in Africa: developing a database for sustainable land use under global change. In: Leigh RA, Johnston AE (Eds), Long-term experiments in Agricultural and Ecological Sciences pp 229-251
Takahashi S, Anwar MR, de Vera SG (2007) Effects of compost and nitrogen fertilizer on wheat nitrogen use in Japanese soils. Agron J 99:1151-1157

Teklay T, Malmer A (2004) Decomposition of leaves from two indigenous trees of contrasting qualities under shadedcoffeee and agricultural land-uses during the dry season at Wondo Genet, Ethiopia. Soil Biol Biochem 36:777-786

Teklay T, Nyberg G, Malmer A (2006) Effects of organic iputs from agroforestry species and urea on crop yield and soil properties at Wondo Genet, Ethiopia. Nutr Cycl Agroecosyst 75:163-173

Tian G, Kang BT, Brussaard L (1993) Mulching effect of plant residues with chemically contrasting compositions on maize growth and nutrients accumulation. Plant Soil 153:179-187

Tian G, Badejo M, Okoh A, Ishida F, Kolawole G, Hayashi Y, Salako F (2007) Effects of residue quality and climate on plant residue decomposition and nutrient release along the transect from humid forest to Sahel of West Africa. Biogeochemistry 86:217-229

Tirol-Padre A, Ladha JK (2006) Integrating rice and wheat productivity trends using the SAS mixed-procedure and meta-analysis. Field Crops Res 95:75-88

van Groenigen KJ, Six J, Hungate BA, de Graaff MA, van Breemen N, van Kessel C (2006) Element interactions limit soil carbon storage. Proc Natl Acad Sci 103:6571-6574

Vanlauwe B, Aihou K, Aman S, Iwuafor ENO, Tossah BK, Diels J, Sanginga N, Lyasse O, Merckx R, Deckers J (2001a) Maize yield as affected by organic inputs and urea in the West African moist Savanna. Agron J 93:1191-1199

Vanlauwe B, Aihou K, Houngnandam P, Diels J, Sanginga N, Merckx R (2001b) Nitrogen management in 'adequate' input maize-based agriculture in the derived savanna benchmark zone of the Benin Republic. Plant Soil 228:61-71

Vanlauwe B, Wendt J, Diels J (2001c) Combined application of organic matter and fertilizer. In: Tian G, Ishida F, Keatinge JDH (Eds) Sustaining Soil Fertility in West Africa. SSSA, American Society of Agronomy, Madison, WI 58:247-279

Vanlauwe B, Diels J, Aihou K, Iwuafor ENO, Lyasse O, Sanginga N, Merckx R (2002a) Direct interactions between $\mathrm{N}$ fertilizer and organic matter: evidence from trials with $15 \mathrm{~N}$-labelled fertilizer. In: Vanlauwe B, Diels J, Sanginga N, Merckx R (eds) Integrated plant nutrient management in Sub-Saharan Africa. CAB International, Wallingford, pp 173-184

Vanlauwe B, Palm CA, Murwira HK, Merckx R (2002b) Organic resource management in Sub-Saharan Africa: validation of a quality-driven decision support system. Agronomie 22:1-8

Vanlauwe B, Diels J, Sanginga N, Merckx R (2005a) Longterm integrated soil fertility management in South-western Nigeria: crop performance and impact on soil fertility status. Plant Soil 273:337-354

Vanlauwe B, Gachengo CN, Shepherd K, Barrios E, Cadisch G, Palm CA (2005b) Laboratory validation of a resource quality-based conceptual framework for organic matter management. Soil Sci Soc Am J 69:1135-1145

Vanlauwe B, Tittonell P, Mukalama J (2006) Within-farm soil fertility gradients affect response of maize to fertiliser application in western Kenya. Nutr Cycl Agroecosyst $76: 171-182$ 
Vanlauwe B, Bationo A, Chianu J, Giller K, Merckx R, Mokwunye U, Ohiokpehai O, Pypers P, Tabo R, Shepherd $\mathrm{K}$ (2010a) Integrated soil fertility management operational definition and consequences for implementation and dissemination. Outl Agric 39:17-24

Vanlauwe B, Kihara J, Chivenge P, Pypers P, Coe R, Six J (2010b) Agronomic use efficiency of $\mathrm{N}$ fertilizer in maizebased systems in sub-Saharan Africa within the context of integrated soil fertility management. Plant Soil. doi:10.1007/s11104-010-0462-7

Workayehu T, Kena K (1998) Residual effects of coffee husk/pulp on grain yield of maize. In: Maize Production Technology for the Future: Challenges and Opportunities, Proceedings of the sixth Eastern and Southern Africa Regional Maize Conference, Addis Ababa, Ethiopia, pp 271-273

Zingore S, Mafongoya PL, Nyamugafata P, Giller KE (2003) Nitrogen mineralization and maize yields following application of tree prunnings on a sandy soil in Zimbabwe. Agrofor Syst 57:199-211

Zingore S, Delve R, Nyamangara J, Giller K (2008) Multiple benefits of manure: the key to maintenance of soil fertility and restoration of depleted sandy soils on African smallholder farms. Nutr Cycl Agroecosyst 80:267-282 